\title{
Effect of Including Treasury Shares in Market Capitalization, EPS, and PER: Evidence from Korea*
}

\author{
Woojin Kim***, Professor, Seoul National University \\ Jieun Im, Ph.D. Candidate, Seoul National University \\ Youngsoo Choi, Professor, Hankuk University of Foreign Studies
}

\begin{abstract}
$<$ Abstract $>$
Market capitalization (cap) is typically determined by multiplying price per share by the number of outstanding shares, excluding treasury shares. Nevertheless, a common practice in Korea has been, and still is, to include treasury shares in market cap. Such practice not only inherently overstates the true magnitude of the market cap by the amount of repurchased shares but also distorts earnings per share (EPS), price earnings ratio (PER), and other per share indicators or price multiples. This study is the first to examine how the practice of including treasury shares affects market cap and other indicators. Our results suggest that the reported market cap is overstated by roughly $6 \%$ on average in the Korean capital market. EPS is understated by $3.6 \%$, and PER is overstated by $4.2 \%$. We also recreate $5 \times 5$ test portfolios based on the Fama-French three factor model after appropriately excluding treasury shares, and find that up to $20 \%$ of constituent stocks may be different for certain test portfolios. These results suggest that Korean academics and practitioners should seriously reconsider the current practice of including treasury shares in calculating market cap and start excluding them to be more consistent with the theory and international practice.
\end{abstract}

Keywords: Market Capitalization; Per Share Indicators; Issued Shares; Shares Outstanding; Treasury Shares

JEL Classification: G10, G11, G15

\footnotetext{
* We are grateful for comments from two anonymous referees. This Research was supported by Research Grant Program from the Korean Securities Association and FnGuide in 2019.

** Corresponding Author. Address: Business School, Seoul National University, 1 Gwanak-ro, Gwanak-gu, Seoul, Korea 08826; E-mail: woojinkim@snu.ac.kr; Tel: +82-2-880-5831; Fax: +82-2-880-5831.
}

Received: October 31, 2019; Revised: January 8, 2020 \& February 19, 2020; Accepted: February 24, 2020 


\title{
자사주 포함 관행이 시가총액 및 주당지표에 미치는 영향"
}

\author{
김 우 진 (서울대학교 교수)** \\ 임 지 은 (서울대학교 박사과정) \\ 최 영 수(한국외국어대학교 교수)
}

\begin{abstract}
시가총액 계산시 발행주식 총수(issued shares)에서 자기주식(treasury shares)을 제외한 유통주식수 (shares outstanding)를 적용하는 것이 일반적인 국제 관행이다. 그럼에도 불구하고 국내 학계 및 업계에서는 지금까지 시가총액 산출시 자사주를 포함하여 왔다. 이러한 관행은 누적된 매입 자사주의 규모만큼 시가 총액을 과대평가하게 될 뿐만 아니라, 주당 순이익(EPS), 주가 수익 비율(PER) 등 관련 주당 지표의 왜곡을 야기할 수 있다. 본 연구에서는 위와 같은 자사주 포함 관행이 국내 상장기업의 시가 총액 및 주당 지표에 어느 정도의 영향을 미치고 있는지 국내 최초로 실증 분석하였다. 분석 결과, 국내 상장기업의 시가 총액은 실제에 비해 평균 $6 \%$ 정도 과대평가된 상태로 보고되고 있는 것을 발견 하였다. EPS는 평균 $3.6 \%$ 과소평가, PER은 평균 $4.2 \%$ 과대평가되고 있는 것으로 나타났다. 자사주를 제외하고 Fama-French 3요인 모델의 $5 \times 5$ Test 포트폴리오를 재구성한 결과, 각 포트폴리오별 구성 종목이 최대 $20 \%$ 까지 차이가 났다. 이러한 결과는 향후 시가총액 및 주당 지표 산출시 국제 관행에 부합하는 자사주 제외 방식을 도입할 필요성이 있음을 시사한다.
\end{abstract}

핵심 단어 : 시가총액, 주당지표, 발행주식수, 유통주식수, 자사주

JEL 분류기호: G10, G11, G15

* 본 논문에 대해 유익한 조언을 해 주신 두 분의 익명의 심사자께 진심으로 감사의 말씀을 드립니다. 본 연구는 한국증권학회-FnGuide 연구지원사업으로 수행되었으며, FnGuide 자료를 사용 하였습니다.

** 연락담당 저자. 주소: 서울특별시 관악구 관악로 1 서울대학교 경영대학 59-702, 08826; E-mail:woojinkim@snu.ac.kr; Tel: 02-880-5831; Fax: 02-880-5831. 


\section{1. 서론}

시가총액은 기업의 규모를 측정하는 대표적인 지표일 뿐만 아니라, 다양한 자산가격결정 이론에서 널리 활용되는 중요한 독립 변수이다. 또한 각종 주가지수 산출시 주가의 평균을 구하는 가중치로도 폭넓게 사용된다. 이러한 시가 총액을 계산함에 있어서 발행주식 총수 (issued shares)가 아닌 유통주식수(shares outstanding)를 사용하는 것이 해외 학계 및 업계의 일반적인 관행이다. ${ }^{1)}$ 유통주식수는 발행주식 총수에서 매입 자사주를 제외하여 산출한다. ${ }^{2}$ 자사주 또는 자기주식(treasury shares)은 기업의 보유 현금이 주주들에게 유출된 결과로 취득 되었으므로 이는 배당과 함께 대표적인 주주환원정책(payout policy)으로 이해하는 것이 재무학계의 일반적인 인식이다. 이에 따라 자사주에는 배당권 및 의결권이 부여되지 않음은 물론이고, 회계상으로도 자산이 아닌 자본의 차감 계정으로 기재한다.

위와 같이 자사주는 자산이 아님에도 불구하고, 국내 관련 업계에서는 시가총액 계산시 유통주식수가 아닌 발행주식 총수를 적용해 왔다. 이는 현재 국내에서 생산되는 각종 연구 및 정책 보고서상 인용되는 시가총액에는 자사주가 포함되어 있음을 의미한다. 현재 코스피 지수도 발행주식 총수를 기반으로 한 시가총액 가중치로 계산되고 있다. ${ }^{3)}$ 이에 따라 자사주 매입 시점 에서는 시가총액에 변동이 없으며, 매입 후 보유중인 자사주는 소각하는 시점에 시가총액에서 제외된다(<표 2-1-1〉 삼성전자 사례 참조). 그런데, 이와 같이 시가총액 계산시 자사주를 포함할 경우 다음과 같은 문제점이 발생한다.

우선, 시가총액이 과대평가되는 문제가 있다. 미국에서는 자사주 매입 시점에 바로 시가총액 에서 제외되지만, 우리는 매입 시점에서는 시가 총액이 불변이고, 추후 소각시점에서 제외되므로, 매입 이후 소각까지 시가총액이 과대평가된다. 이 기간 동안에는 회계상 주주지분에는 자사주가 제외되어 있는 반면, 시가총액에는 자사주가 포함되어 양자간에 괴리가 발생하며 회계지표와 시장지표가 불일치하게 된다. 시가총액의 과대평가는 그 자체로도 중요하지만, 시가총액을 가중치로 하는 각종 주가지수의 산출에 왜곡을 가져올 수 있다는 점이 보다 더 중요한 이슈인 것이다. 자사주를 상대적으로 더 많이 보유한 기업이 그렇지 않은 기업에 비해 주가 지수 산출시 더 높은 가중치를 부여 받아 부당하게 지수 영향력이 증대되기 때문이다.

1) Brealey et al.(2010) 등 재무 교과서 및 Wall Street Journal 참조.

2) 현재 국내 상법에는 shares outstanding 개념이 별도로 규정되어 있지 않다. 다만 상장회사의 정기 보고서 상에 ‘주식의 총수 등' 항목에서 이를 '유통주식수’라 칭하고 있다. 아울러 일반기업회계기준 제26장 기본주당이익의 문단 26.13에서 ““유통'이라 함은 주식이 발행된 후 재취득되지 않은 상태를 말한다.”라 되어 있다.

3) KRX 주가지수 산출 방법(2016) 및 KOSPI 200 지수산출방법(2017) 참조. 한편, KOSPI200 지수는 발행주식 총수가 아닌, 유동주식수를 기반으로 산출되고 있다. 유동주식수(free float shares)는 유통주식수에서 최대주주 지분 등 유통이 제한된 비유동주식수를 제외한 실제 거래 가능한 주식수이다. 비유동주식수에는 최대주주 및 특수관계인 보유분, 우리사주조합 보유분, 정부 보유분 $5 \%$ 이상 보유한 경우), 일부 보호예수주식 등 유통이 제한되었다고 인정되는 주식 등이 해당된다. 
Effect of Including Treasury Shares in Market Capitalization, EPS, and PER

다음, 주당 순이익(EPS: Earnings Per Share)이 과소평가될 수 있다. EPS는 1주당 창출되는 이익의 정도를 나타내는 지표로 전체 당기순이익을 주식수로 나누어 산출한다. 그런데, 시가총액 계산시 자사주를 포함하는 관행에 따라 EPS 계산시에도 분모에 유통 주식수가 아닌 발행주식 총수를 적용함으로써 분모가 과대 계상되고 따라서 EPS가 과소평가 된다. 한편, 자사주에는 배당금이 지급되지 않는 점을 고려하여 주당 배당금(DPS: Dividend Per Share) 산출시에는 분모에 발행주식 총수에서 자사주를 제외한 유통주식수를 적용하고 있다. 이처럼 $\mathrm{EPS}$ 와 DPS에 적용되는 주식수가 서로 상이하여 일관성이 결여되어 있다는 점 또한 중요한 문제이다. 관련하여, BPS(Book-value Per Share)는 기업의 순자산을 주식 수로 나누어 산출하는데, 기존 산식의 분자(순자산)는 회계지표로 자사주가 제외되어 있으나, 분모(기말발행주식수)에는 자사주가 포함되어 역시 일관성이 없다.

아울러 대표적인 상대가치 평가지표로 실무에서 널리 활용되는 주가 수익 비율(PER: Price Earnings Ratio)이 과대평가되는 문제가 있다. PER는 (1) 전체 시가총액을 전체 순이익으로 나누거나, (2) 주당 가격(주가)을 주당 순이익(EPS)으로 나누어 산출하는데, (1)의 경우 분자가 과대평가되어 있고, (2)의 경우 분모가 과소평가되어 있어서 결과적으로 PER이 과대평가된다.

이와 같이 PER의 과대평가는 IPO 기업의 공모 가액의 과대평가로 이어질 수 있다는 점에서 특히 심각하다고 볼 수 있다. $\mathrm{IPO}$ 의 가장 중요한 목적 중의 하나가 자금 조달인 것을 고려할 때, IPO 이전의 비상장 기업이 보유 현금을 지급하고 자사주를 매입했을 가능성은 희박할 것이다. 반면 비교 대상이 되는 동종업계 유사기업군(peer group)에 속하는 상장 기업들이 자사주를 보유하고 있다면, 해당 기업들의 PER가 자사주 보유분만큼 과대평가 되어 있을 것이고, 이는 IPO 기업의 공모가격에 그대로 반영된다. IPO 공모가격이 과대평가되었을 경우, 추후 공모주 청약을 한 일반투자자들의 투자 수익에 부정적인 영향을 미칠 수도 있다.

마지막으로 시가총액 계산시 자사주를 포함할 경우 자사주를 자산으로 인정하는 현재의 실무상 관행을 간접적으로 정당화하는 근거를 제공하게 된다. 예컨대, 현재 국내에서는 경영권 방어 목적 및 지주회사 전환시 자사주 부활 등의 목적으로 자사주를 과다 보유하는 경향이 있는데, 시가총액에 자사주를 포함하는 것은 자사주를 자산으로 인정하는 입장에 의하면 자연스러운 논리적 귀결이기 때문이다. 김우진, 임지은(2017)에 의하면, 국내 기 업들은 취득한 자사주의 대부분을 소각하지 않고 보유하거나 재매각하는 경향이 있으며, 지배 구조 수준과 소각 간에는 양(+)의 관계가, 처분 간에는 음(-)의 관계가 발견되었다. 현재 국회에는 위와 같이 자사주를 자산으로 인정하는 관행을 금지하는 법안이 다수 발의되어 있다 (박용진 의원 발의 상법 개정안(2016. 7. 13. 등)).

본 연구에서는 이처럼 시가 총액에 자사주를 포함하는 국내 관행이 실제로 시가 총액 및 주당 지표에 미치는 왜곡의 정도를 최초로 계량적으로 분석하였다. 보다 구체적으로는 자사주를 제외하고 시가총액 및 주당지표를 재계산 하였을 경우, 시가총액 및 주당지표가 어떻게 
한국증권학회지 제49권 2호 (2020)

변하는지를 측정하였다. 분석 기간은 자사주 관련 자료가 입수 가능한 2003년 이후, 2019년 까지이며, 분석 대상 기업은 유가증권시장 및 코스닥시장에 상장된 비금융기업 전체이다.

분석결과, 자사주가 포함된 시가 총액은 자사주를 제외한 경우에 비해 평균 약 $6 \%$ 정도 과대 평가되어 있는 것으로 나타났다. 유가증권시장 시가총액 상위 50 대 기업 중 자사주에 의해 시가총액이 과대평가된 기업은 38 개이고, 이 중에서 규모가 제일 큰 기업은 SK로 자사주 제외 시가총액 대비 $26 \%$ 나 과대평가되어 있는 것으로 나타났다. 삼성물산은 과대평가 비율이 $16 \%$ 로 괴리율 2위를 차지하였다. 한편 삼성전자는 2018년 말에 보유중인 자사주를 전량 소각하여, 현재 보유중인 자사주가 없고, 따라서 과대평가 비율은 0이다. 코스닥 시장 시가총액 상위 50 대 기업 중 자사주에 의해 시가총액이 과대평가된 기업은 34 개이다. 이 중에서 과대평가 비율이 가장 높은 기업은 하림지주로 괴리율이 $24 \%$ 에 달했으며, 자사주를 제외하고 시가총액 순위를 다시 평가할 경우 하림지주의 시가총액 순위는 기존 28 위에서 37 위로 9단계 하락하는 것으로 나타났다. 업종별로는 정보통신업 및 전문, 과학 및 기술 서비스업, 사업시설관리업의 괴리율이 전체(자사주 보유) 표본에서는 $7 \%(8 \%)$ 이상으로 비교적 높게 나타났는데, 이들 업종은 향후 지주회사 전환시 자사주를 활용하기 위해 상대적으로 많은 자사주를 보유하고 있는 것으로 추정해 볼 수 있다.

한편, 주당 순이익(EPS)의 경우, 계산시 분모에서 제외되어야 할 자사주가 불필요하게 포함 됨에 따라 자사주를 제외하는 경우에 비해 전체(자사주 보유) 표본에서는 평균 약 3.6\%(5.2\%) 정도 과소평가되어 있는 것으로 나타났다. 주가 수익 비율(PER)은 자사주가 포함됨에 따라 그렇지 않은 경우에 비해 전체(자사주 보유) 표본에서는 평균 약 $4.2 \%$ (6.1\%) 정도 과대평가 되어 있는 것으로 나타났는데, 이는 PER 과대평가 기업이 동종업계 유사기업군에 포함될 경우, 상대가치평가에 따른 $\mathrm{IPO}$ 공모가격이 과대 산정될 수 있음을 시사한다.

마지막으로 위와 같은 자사주 포함 관행이 자산가격결정모형 추정에 어떠한 영향을 미치는 지를 평가하기 위해 자사주를 제외하고 Fama-French 3요인 모형의 3요인과 $5 \times 5$ 검증 포트폴리오를 재구성해 보았다. 분석 결과 자사주 포함여부에 따른 3요인(Rm-Rf, SMB, $\mathrm{HML})$ 의 요약통계량은 큰 차이가 없는 것으로 나타났다. 반면, $5 \times 5$ 검증 포트폴리오의 경우는 포트폴리오별로 최대 20\%까지 구성 종목에 차이가 있는 것을 발견하였다.

종합하면, 시가총액 및 주당지표 계산시 자사주를 포함하는 국내의 관행이 시가 총액 및 주당지표에 일정 수준의 영향을 미치고 있음을 알 수 있었다. 보다 구체적으로는 전체 (자사주 보유) 표본에서는 시가총액은 평균 약 $6 \%(8 \%)$, PER은 약 4.2\%(6.1\%) 과대평가된 상태로, 그리고 $\mathrm{EPS}$ 는 평균 약 3.6\%(5.2\%) 과소평가된 상태로 보고 된다. 이러한 결과는 향후 시가총액 및 주당지표 산출시 국제 기준에 부합하는 자사주를 제외한 유통주식수 기준을 도입하여 논리적 타당성 및 회계 지표와의 일관성을 제고할 필요가 있음을 시사한다.

본 연구는 다음과 같이 구성되었다. 서론에 이어 제 2장에서는 자료 및 표본, 주요 변수의 구성에 대해 설명한다. 제 3 장에서는 실증분석 결과를 기술하고, 제 4 장에서는 위와 같은 실증분석 결과를 토대로 정책적 시사점을 포함한 결론을 제시한다. 


\section{2. 연구 표본의 구성}

\section{1 분석대상 표본 및 자료수집}

본 연구는 한국거래소 유가증권 시장과 코스닥 시장에 상장되어 있는 모든 기업을 분석대상 으로 하였으며, 금융산업은 자본구조에 있어서 제조기업들과 차이가 존재하므로 제외하였다. 표본기간은 자기주식수 자료를 확보할 수 있는 2003년부터 2019년 7월까지고, 자기주식의 포함여부에 따른 시가총액, $\mathrm{EPS}$ 및 PER의 차이를 보이기 위해 자기주식수를 포함한 기타 재무회계자료와 산업분류 등 일반적인 사항에 대한 자료는 FnGuide 사에서 제공하는 데이터 베이스인 DataGuide에서 추출하였다.

또한 자산가격결정모형으로는 Fama and French(1993)의 3요인 모형(factor model) 방법론을 한국시장에 적용하여 구축하였으며, 2003년 1월부터 2019년 7월까지 유가증권과 코스닥시장에 상장된 보통주를 그 대상으로 하였다. Fama and French(1993)의 방법을 따라 자본잠식 종목과 금융 업종 그리고 결산월이 12 월이 아닌 회사는 분석 대상에서 제외하였다. 본 분석에 필요한 모든 주식시장 및 재무제표 자료는 위와 마찬가지로 $\mathrm{Fn}-$ Guide사의 데이터베이스인 DataGuide에서 추출하였다.

\section{2 변수 구성 및 정의}

\subsection{1 시가총액, EPS, PER}

자사주 포함 여부에 따른 각각의 시가총액, $\mathrm{EPS}$ 그리고 PER을 구축하기 위해 해당년도 말의 보통주 종가, 발행주식총수, ${ }^{4}$ 자기주식수 및 당기순이익을 사용하였으며, EPS 계산 시에 사용하는 주식수는 해당년도의 평균발행주식수(EPS)와 수정평균발행주식수(수정EPS)를 이용 하였다. 수정평균발행주식수는 평균발행주식수에 주식조정계수를 적용한 주식수를 의미한다. 또한 $\mathrm{EPS}$ 의 분자로는 연결재무제표에서는 지배주주순이익을 사용하고, 별도 재무제표에서는 당기순이익을 사용하여 계산하였다.

\begin{tabular}{|c|c|c|c|}
\hline & 자사주포함(기존) & 비교 & 자사주차감 \\
\hline [1] 시가총액 & 주가 $\times$ 발행주식수 & $>$ & 주가 $\times($ 발행주식수 - 자기주식수 $)$ \\
\hline [2] EPC & 당기순이익 & & 당기순이익 \\
\hline [2] EPS & (수정)평균발행주식수 & $<$ & (수정)평균발행주식수-자기주식수 \\
\hline [3] PER & $\begin{array}{l}\text { 주가 } \\
\mathrm{EPS}\end{array}$ & $>$ & $\frac{\text { 주가 }}{\text { 자사주차감 } \mathrm{EPS}}$ \\
\hline
\end{tabular}

4) 상장기업의 상장주식수는 현재 거래할 수 있도록 상장된 주식수로, 신규발행 혹은 유상증자 이후 상장되기 이전까지 일시적으로 발행주식총수와 상장주식수가 다를 수는 있지만 발행주식총수를 의미한다. 
여기서 주가는 종가를 의미하며, $\mathrm{EPS}$ 를 산정하는 산식에서 차감되는 자기주식수는 평균 자기 주식수를 의미한다.

자사주 포함 여부에 따른 괴리율은 자사주를 차감한 값 대비 기존 자사주를 포함한 값과 차감한 값의 차이로 정의하며, 현재 자사주를 포함한 시가총액 및 $\mathrm{PER}$ 이 자사주를 차감한 값에 대비하여 과대계상 되어있는 정도와 $\mathrm{EPS}$ 가 과소계상 되어 있는 정도를 나타내고자 한다.

\begin{tabular}{|c|c|c|c|}
\hline & 괴리율 & 식도출 결과 & 식정리 \\
\hline \multirow{2}{*}{ [1] 시가총액 $=\mathrm{MC}$} & $\underline{\mathrm{MC}-\mathrm{MC}_{\mathrm{ts}}}$ & & \multirow{3}{*}{ 괴리율 } \\
\hline & $\mathrm{MC}_{\mathrm{ts}}$ & $t s$ & \\
\hline [2] PER & $\frac{\text { PER }- \text { PER }_{\text {ts }}}{\text { PER }_{\text {ts }}}$ & $s h r-t s$ & \\
\hline \multirow{2}{*}{ [3] EPS } & $\underline{E P S-E P S_{t s}}$ & $t s$ & 괴리율 \\
\hline & $\mathrm{EPS}_{\mathrm{ts}}$ & $s h r$ & $1+$ 괴리율 \\
\hline
\end{tabular}

여기서 ts는 자기주식수, shr은 시가총액을 계산할 때는 발행주식수, PER 혹은 EPS를 계산할 때는 (수정)평균발행주식수를 의미한다. 세 번째 열의 식도출은 2 번째 열의 괴리율을 ts와 $\mathrm{shr}$ 로 표현한 것이고 네 번째 열의 식정리는 $\mathrm{ts} /(\mathrm{shr}-\mathrm{ts})$ 를 괴리율이라 명명할 경우, -ts/shr를 괴리율로 표현한 것이다.

\subsection{2 요인 모형(Factor Model)}

본 연구의 요인 모형은 Fama and French(1993)의 3요인 모형 방법론을 한국시장의 주간 자료에 적용하여 구축한 것이다.

$$
R_{t}-R F_{t}=\alpha+\beta\left[R M_{t}-R F_{t}\right]+s S M B_{t}+h H M L_{t}+e_{t}
$$

$$
\begin{aligned}
& R_{t}=\text { 주식의 } \mathrm{t} \text { 기 수익률 } \\
& R F_{t}=\mathrm{t} \text { 기 무위험수익률 } \\
& \quad=\left(\left(1+0.01 \times \overline{R F}_{t}\right)^{\frac{1}{52}}-1\right) \times 100 \\
& \overline{R F}_{t}=\mathrm{t} \text { 기 } 364 \text { 일 만기 통안채 } \\
& R M_{t}=\mathrm{t} \text { 기 시장요인 포트폴리오 수익률 } \\
& S M B_{t}=\mathrm{t} \text { 기 규모요인 포트폴리오 수익률 } \\
& H M L_{t}=\mathrm{t} \text { 기 가치요인 포트폴리오 수익률 }
\end{aligned}
$$

모방포트폴리오의 주별 수익률을 계산하기 위해 FnGuide에서 제공하는 2003년부터 2019년 7월까지 한국 유가증권과 코스닥시장에 상장되어 있거나 상장된 바 있는 비금융권 보통주의 주별 주가자료를 사용하였다. 
Effect of Including Treasury Shares in Market Capitalization, EPS, and PER

먼저 주식의 수익률 $R_{t}$ 을 계산하기 위해 FnGuide에서 제공하는 현금배당반영 수정주가로 계산된 수익률을 사용하였다. 두 번째로 무위험수익률 $R F_{t}$ 는 한국은행에서 제공하는 364 일 만기 통안채 금리를 FnGuide로부터 입수하여 사용하였다. 이때 공시된 금리 $\overline{R F}_{t}$ 는 백분율로 연율화되었으므로 위의 공식에 따라 $R_{t}$ 의 주간 단위와 통일하여 수익률을 계산하였다. 다음으로 시장요인 포트폴리오 수익률의 대용치인 $R M_{t}$ 을 계산하기 위해 2003년부터 2019년 7 월까지 한국 유가증권과 코스닥시장에 상장되어 있거나 상장된 바 있는 보통주의 배당을 고려한 수익률과 시가총액 시계열을 DataGuide로부터 취득하여 시가총액 가중평균 수익률을 구하였다. 이때 자사주포함 여부에 따른 차이를 보여주기 위해 시가총액은 자사주포함과 자사주 차감 두 경우로 나누어서 분석을 진행하였다.

마지막으로 $S M B_{t}$ 와 $H M L_{t}$ 는 Fama and French(1993)가 제시한 대형주 대비 소형주의 초과수익률, 성장주 대비 가치주의 초과수익률을 나타내는 변수다. 먼저 기업의 규모(Size)에 따라 구분을 하는데, 보통주 시가총액의 중앙값을 기준으로 Big과 Small 두 개의 포트폴리오를 구성한다. 시가총액은 보통주 종가에 발행주식수를 곱하여 계산하며 $R M_{t}$ 계산시와 마찬가지로 자사주포함 여부에 따라 시가총액을 두 경우로 나누어 구축한다. 이때 t년도의 6월 말 시가총액을 기준으로 분류하여 $\mathrm{t}$ 년도의 7 월 초부터 $\mathrm{t}+1$ 년도의 6 월 말까지 포트폴리오 구성을 고정시킨다. 이와는 독립적으로 각각의 포트폴리오를 장부-시장가 비율(BE/ME: ratio of Book Equity to Market Equity)을 기준으로 상위 $30 \%$, 중위 $40 \%$, 하위 $30 \%$ 로 분류하며, 장부-시장가 비율을 구하기 위한 장부가(BE)는 보통주 자본금에 자본잉여금과 이익잉여금을 더하고 자기주식을 차감한 뒤 이연 법인세부채를 더하여 계산하였고, 시장가(ME)는 보통주 종가에 발행주식수를 곱하여 계산하였다. 장부-시장가 비율 구축시 이용되는 시장가는 자사주 포함 여부에 따라 두 가지 경우로 구성하여 분석에 이용한다. 이로부터 6개의 포트폴리오 SmallLow, Small-Medium, Small-High, Big-Low, Big-Medium, Big-High을 구성하여 이들의 수익률을 아래와 같이 계산한다.

\begin{tabular}{lccc}
\hline & Low(30\%) & Medium(40\%) & High(30\%) \\
\hline Small(50\%) & S/L & S/M & S/H \\
Big(50\%) & B/L & B/M & B/H \\
\hline
\end{tabular}

t기의 각 포트폴리오의 수익률을 위의 표와 같이 정의하면 $S M B_{t}$ 와 $H M L_{t}$ 는 각각 아래와 같이 나타낼 수 있다.

$$
\begin{gathered}
S M B_{t}=\frac{S L_{t}+S M_{t}+S H_{t}}{3}-\frac{B L_{t}+B M_{t}+B H_{t}}{3} \\
H M L_{t}=\frac{S H_{t}+B H_{t}}{2}-\frac{S L_{\mathrm{t}}+B L_{t}}{2}
\end{gathered}
$$




\section{3. 실증 분석 결과}

본 연구는 자기주식수 자료를 확보할 수 있는 2003년부터 2019년 7월까지 자료를 사용하여 자기주식의 포함여부에 따른 시가총액, EPS, PER의 현황 및 변화추이를 분석하였다. 아울러 PER의 과대평가가 IPO 공모가격에 미치는 영향에 대한 사례연구와 Fama-French 3요인 모형에 미치는 영향을 조사하였다.

\section{1 시가총액}

\subsection{1 시가총액 현황 분석}

<표 1>과 <그림 1-1>은 2003년부터 2019년까지 유가증권시장과 코스닥시장에 상장된 기업들의 연도별 시가총액의 합을 자사주 포함과 차감으로 구분하여 표와 그림으로 변화 추이를 보여준다. 패널 $\mathrm{A}$ 는 전체 표본에 대한 분석이고 패널 $\mathrm{B}$ 는 자사주를 보유하고 있는 부표본(sub sample)에 대한 분석이다.

\section{〈표 1〉연도별 시가총액 현황}

이 표는 2003년부터 2019년까지 유가증권시장과 코스닥시장에 상장된 기업들의 연도별 시가총액 총합을 나타낸다. 패널A는 전체 표본에 대한 분석이고, 패널 $\mathrm{B}$ 는 자사주를 보유하고 있는 부표본에 대한 분석이다. 시가총액은 해당 년도 말 (보통주 종가) $\times$ (보통주 발행주식수)로 구하였으며, 2019년은 7 월 말 기준으로 계산하였다. [1]은 자사주를 포함한 시가총액(=종가 $\times$ 발행주식수)이고, [2]는 발행

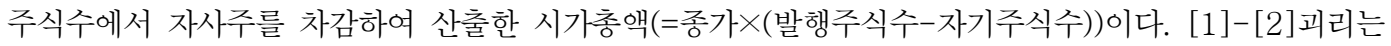
두 그룹의 시가총액의 차이를 나타내고, 괴리율은 자사주를 차감한 시가총액 대비 두 그룹의 시가총액 차이(=[1]-[2]괴리/[2]자사주차감)를 나타내며, 자사주 보유비중은 전체 표본 중에 자사주를 보유한 기업의 비중을 의미한다. 단위는 조 원이다.

패널 $\mathrm{A}$ : 전체표본

(단위: 조 원)

\begin{tabular}{ccccccc}
\hline 연도 & 관측치수 & [1]자사주포함 & [2]자사주차감 & [1]-[2] 괴리 & 괴리율 & 자사주 보유비중 \\
\hline 2003 & 1,340 & 308.5 & 288.5 & 20.0 & $6.93 \%$ & $63.96 \%$ \\
2004 & 1,386 & 358.4 & 336.8 & 21.6 & $6.41 \%$ & $67.46 \%$ \\
2005 & 1,434 & 559.3 & 527.1 & 32.2 & $6.11 \%$ & $60.18 \%$ \\
2006 & 1,464 & 603.9 & 565.8 & 38.1 & $6.73 \%$ & $62.84 \%$ \\
2007 & 1,536 & 843.1 & 791.3 & 51.8 & $6.55 \%$ & $63.87 \%$ \\
2008 & 1,581 & 515.4 & 480.4 & 35.0 & $7.29 \%$ & $71.22 \%$ \\
2009 & 1,632 & 806.9 & 761.1 & 45.8 & $6.02 \%$ & $69.85 \%$ \\
2010 & 1,658 & $1,021.6$ & 967.0 & 54.6 & $5.65 \%$ & $68.09 \%$ \\
2011 & 1,661 & 975.1 & 922.4 & 52.7 & $5.71 \%$ & $68.93 \%$ \\
2012 & 1,637 & $1,072.6$ & $1,013.3$ & 59.3 & $5.85 \%$ & $68.66 \%$ \\
2013 & 1,658 & $1,095.6$ & $1,036.0$ & 59.6 & $5.75 \%$ & $67.01 \%$ \\
2014 & 1,696 & $1,137.5$ & $1,075.4$ & 62.1 & $5.77 \%$ & $66.16 \%$ \\
2015 & 1,794 & $1,251.3$ & $1,183.0$ & 68.3 & $5.77 \%$ & $65.89 \%$ \\
2016 & 1,847 & $1,290.7$ & $1,215.5$ & 75.2 & $6.19 \%$ & $65.73 \%$ \\
2017 & 1,905 & $1,622.2$ & $1,550.4$ & 71.8 & $4.63 \%$ & $67.61 \%$ \\
2018 & 1,965 & $1,371.6$ & $1,325.7$ & 45.9 & $3.46 \%$ & $69.41 \%$ \\
2019 & 1,963 & $1,340.4$ & $1,296.3$ & 44.1 & $3.40 \%$ & $69.03 \%$ \\
\hline 전체평균 & 28,157 & 951.4 & 902.1 & 49.3 & $5.78 \%$ & $66.82 \%$ \\
\hline
\end{tabular}


Effect of Including Treasury Shares in Market Capitalization, EPS, and PER

〈표 1〉연도별 시가총액 현황(계속)

패널 $\mathrm{B}$ : 자사주 보유 표본

\begin{tabular}{cccccc}
\hline 연도 & 관측치수 & [1]자사주포함 & [2]자사주차감 & [1]-[2]괴리 & 괴리율 \\
\hline 2003 & 857 & 262 & 241.9 & 20.1 & $8.31 \%$ \\
2004 & 935 & 301.4 & 279.9 & 21.5 & $7.68 \%$ \\
2005 & 863 & 452.2 & 419.9 & 32.3 & $7.69 \%$ \\
2006 & 920 & 458.9 & 420.9 & 38.0 & $9.03 \%$ \\
2007 & 981 & 662.8 & 610.9 & 51.9 & $8.50 \%$ \\
2008 & 1,126 & 431.7 & 396.8 & 34.9 & $8.80 \%$ \\
2009 & 1,140 & 659.1 & 613.3 & 45.8 & $7.47 \%$ \\
2010 & 1,129 & 821.9 & 767.2 & 54.7 & $7.13 \%$ \\
2011 & 1,145 & 799.6 & 747 & 52.6 & $7.04 \%$ \\
2012 & 1,124 & 888.5 & 829.2 & 59.3 & $7.15 \%$ \\
2013 & 1,111 & 914.9 & 855.4 & 59.5 & $6.96 \%$ \\
2014 & 1,122 & 946.8 & 884.7 & 62.1 & $7.02 \%$ \\
2015 & 1,182 & $1,015.4$ & 947.1 & 68.3 & $7.21 \%$ \\
2016 & 1,214 & $1,065.8$ & 990.6 & 75.2 & $7.59 \%$ \\
2017 & 1,288 & $1,332.8$ & 1261 & 71.8 & $5.69 \%$ \\
2018 & 1,364 & 886.5 & 840.6 & 45.9 & $5.46 \%$ \\
2019 & 1,355 & 850.7 & 806.6 & 44.1 & $5.47 \%$ \\
\hline 전체평균 & 18,856 & 750.1 & 700.8 & 49.3 & $7.31 \%$ \\
\hline
\end{tabular}

〈그림 1-1〉시가총액 추이

이 그림은 2003년부터 2019년까지 유가증권시장과 코스닥시장에 상장된 기업들의 연별 시가총액의 합과 괴리율을 나타낸 그래프이다. 시가총액은 해당 년도 말 (보통주 종가) $\times$ (발행주식수)로 구하였으며 2019년은 7월 말 기준으로 계산하였다. [1]은 자사주를 포함한 시가총액(=종가발행주식수)이고, [2]는 발행주식수에서 자사주를 차감하여 산출한 시가총액(=종가 $\times($ 발행주식수-자기주식수 $)$ 이다. 괴리율은 자사주를 차감한 시가총액 대비 두 그룹의 시가총액 차이를 나타내며, 단위는 퍼센트(\%)이다. 시가총액 단위는 조 원이다.

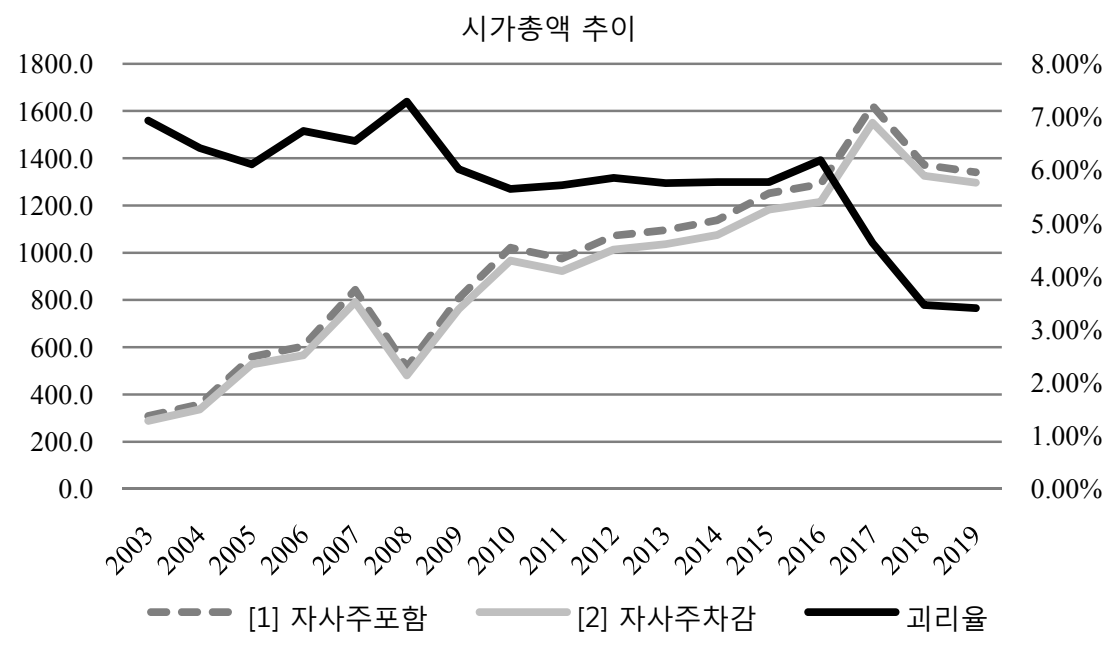


2003년도부터 자사주 차감 여부와 무관하게 시가총액은 증가하는 추세이고, 2008년도에는 금융위기 발생으로 시가총액이 크게 감소하였으며, 2017년도에는 BT(Bio Tech) 업종의 활황으로 크게 증가하였음을 알 수 있다. 반면에 자사주를 차감한 시가총액 대비 두 그룹 간의 시가총액 차이를 괴리율로 살펴보면 추세적으로 감소하고 있으나 자사주 보유비중은 2008년 금융위기 시점에서 고점을 찍은 후 감소하다가 다시 증가하여 2009년 수준에 근접하고 있다. 특히 2017년 이후에 자사주를 보유한 기업 비중은 증가하였으나 괴리율이 크게 감소한 현상은 자사주를 보유할 때 그 보유 규모가 축소되었음을 암시하고 있다.

<그림 1-2〉는 자사주 포함 여부에 따른 두 그룹간 시가총액 차이를 보여준다. 2003년 이후 시가총액은 지속적으로 상승한 반면에 괴리율은 소폭 감소하여 2016년까지는 시가 총액 차이가 지속적으로 증가하였다. 하지만 2017년 이후 괴리율이 큰 폭으로 감소할 뿐 아니라 2018년 이후 시가총액도 감소하여 시가총액 차이도 2009년 수준으로 떨어졌음을 알 수 있다.

〈그림 1-2〉 자사주 포함 여부에 따른 그룹간 시가총액 괴리

이 그림은 2003년부터 2019년까지 유가증권시장과 코스닥시장에 상장된 기업들의 자사주를 포함한 시가총액과 자사주를 차감한 시가총액의 괴리(<표 1>의 [1]-[2]괴리)를 나타낸 그래프이다. 단위는 조 원이다.

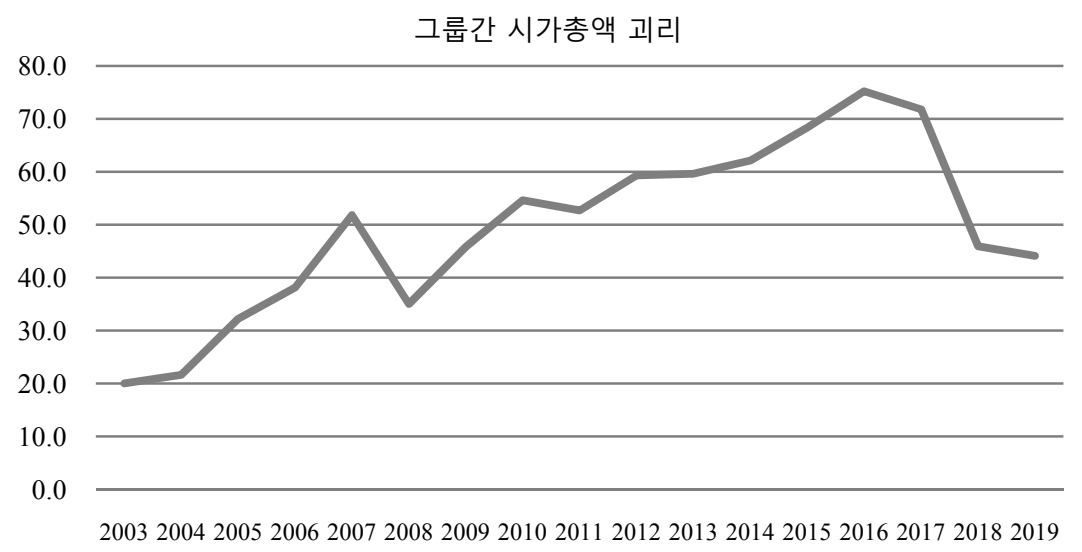

\subsection{2 시가총액 순위 변동}

<표 2-1>은 유가증권시장에 상장되어 있는 기업들의 2019년 7월 말 기준 1위부터 50위 까지의 시가총액 순위를 나타낸다. 상위 50 개 기업의 시가총액 괴리율 평균은 $3.92 \%$, 중간 값은 $2.30 \%$, 왜도(skewness)는 1.96, 첨도(kurtosis)는 4.92로 괴리율은 평균을 중심으로 오른쪽으로 꼬리가 두꺼운 분포를 갖는다. 특히 SK의 괴리율은 $26.04 \%$ 로 자사주 제외 시가총액 대비 $26 \%$ 나 과대평가되었고 자사주를 제외할 경우 시가총액 순위가 18 위에서 20 위로 2 단계 하락하게 된다. 상위 50 개 기업의 시가총액 순위 변동은 평균적으로 1 단계 임을 알 수 있다. 아울러 상위 50 개 기업 중에서 과대평가된 기업은 38 개 기업이고 이들의 
Effect of Including Treasury Shares in Market Capitalization, EPS, and PER

괴리율 평균은 $5.16 \%$, 중간값은 $4.70 \%$, 왜도(skewness)는 1.74 , 첨도(kurtosis)는 3.94 로 역시 평균을 중심으로 오른쪽으로 꼬리가 두꺼운 분포를 갖는다.

〈표 2-1〉 유가증권시장 시가총액 순위

이 표는 유가증권시장에 상장되어 있는 기업들의 2019년 7 월 말 기준 1 위부터 50 위까지의 시가 총액 순위를 나타낸다. [1]은 자사주를 포함한 시가총액(=종가 $\times$ 발행주식수)이고, [2]는 발행 주식수에서 자사주를 차감한 시가총액(=종가 $\times$ (발행주식수-자기주식수))이다. [1]-[2] 괴리에서는 자사주 포함 여부에 따른 시가총액의 금액 차이와 시가총액 순위의 변화, 그리고 시가총액 괴리율을 보여주며, [2]열에 나열된 회사기준으로 계산하였다. 단위는 십억 원이다.

(단위: 십억 원)

\begin{tabular}{|c|c|c|c|c|c|c|c|}
\hline \multicolumn{3}{|c|}{ [1] 자사주 포함 시가총액 } & \multicolumn{2}{|c|}{ [2] 자사주 차감 시가총액 } & \multicolumn{3}{|c|}{ [1] - [2] 괴리 } \\
\hline 순위 & 회사명 & 시총 & 회사명 & 시총 & 시총 & 순위 & 괴리율 \\
\hline 1 & 삼성전자 & $268,341.7$ & 삼성전자 & $268,341.7$ & 0 & - & 0.00 \\
\hline 2 & SK하이닉스 & $55,401.0$ & SK하이닉스 & $52,052.5$ & $3,348.4$ & - & 6.43 \\
\hline 3 & 현대차 & $27,242.7$ & 현대차 & $25,847.9$ & $1,394.8$ & - & 5.40 \\
\hline 4 & 현대모비스 & $23,445.4$ & LG화학 & $22,853.6$ & 547.8 & $\triangle 2$ & 2.40 \\
\hline 5 & NAVER & $23,403.5$ & 현대모비스 & $22,795.2$ & 650.2 & $\boldsymbol{\nabla} 1$ & 2.85 \\
\hline 6 & LG화학 & $23,401.4$ & 셀트리온 & $20,808.5$ & 173.4 & $\triangle 1$ & 0.83 \\
\hline 7 & 셀트리온 & $20,981.8$ & NAVER & $20,653.6$ & $2,749.9$ & $\boldsymbol{\nabla} 2$ & 13.31 \\
\hline 8 & SK텔레콤 & $20,347.9$ & 삼성바이오로직스 & $18,427.0$ & 0 & $\triangle 3$ & 0.00 \\
\hline 9 & LG생활건강 & $19,038.6$ & SK텔레콤 & $18,111.2$ & $2,236.7$ & $\nabla 1$ & 12.35 \\
\hline 10 & POSCO & $18,919.5$ & $\mathrm{LG}$ 생활건강 & $17,870.3$ & $1,168.3$ & $\nabla 1$ & 6.54 \\
\hline 11 & 삼성바이오로직스 & $18,427.0$ & 한국전력 & $17,397.2$ & 0 & $\triangle 1$ & 0.00 \\
\hline 12 & 한국전력 & $17,397.2$ & POSCO & $17,385.1$ & $1,534.4$ & $\boldsymbol{\nabla} 2$ & 8.83 \\
\hline 13 & 기아차 & $17,349.6$ & 기아차 & $17,159.9$ & 189.7 & - & 1.11 \\
\hline 14 & 삼성SDI & $17,294.3$ & 삼성SDI & $16,456.4$ & 837.8 & - & 5.09 \\
\hline 15 & 삼성물산 & $17,091.1$ & 삼성에스디에스 & $16,166.2$ & 5.8 & $\triangle 1$ & 0.04 \\
\hline 16 & 삼성에스디에스 & $16,172.0$ & 삼성물산 & $14,728.1$ & $2,362.9$ & $\nabla 1$ & 16.04 \\
\hline 17 & SK이노베이션 & $15,580.4$ & SK이노베이션 & $14,653.3$ & 927.1 & - & 6.33 \\
\hline 18 & SK & $14,670.1$ & LG & $12,313.9$ & 6.7 & $\triangle 2$ & 0.05 \\
\hline 19 & $\mathrm{KT} \& \mathrm{G}$ & $13,152.6$ & $K T \& G$ & $12,096.2$ & $1,056.4$ & - & 8.73 \\
\hline 20 & LG & $12,320.6$ & SK & $11,639.4$ & $3,030.7$ & $\boldsymbol{\nabla} 2$ & 26.04 \\
\hline 21 & 엔씨소프트 & $11,412.2$ & 엔씨소프트 & $10,712.0$ & 700.2 & - & 6.54 \\
\hline 22 & 카카오 & $10,726.6$ & LG전자 & $10,359.5$ & 48.5 & $\triangle 1$ & 0.47 \\
\hline 23 & LG전자 & $10,408.0$ & S-Oil & $10,267.6$ & 0 & $\triangle 1$ & 0.00 \\
\hline 24 & S-Oil & $10,267.6$ & 카카오 & $10,182.6$ & 544.0 & $\boldsymbol{\nabla} 2$ & 5.34 \\
\hline 25 & 고려아연 & $8,114.1$ & 롯데케미칼 & $7,797.7$ & 0 & $\triangle 1$ & 0.00 \\
\hline 26 & 롯데케미칼 & $7,797.7$ & 고려아연 & $7,599.9$ & 514.2 & $\nabla 1$ & 6.77 \\
\hline 27 & 넷마블 & $7,791.3$ & 아모레퍼시픽 & $7,562.4$ & 66.4 & $\triangle 1$ & 0.88 \\
\hline 28 & 아모레퍼시픽 & $7,628.8$ & 넷마블 & $7,542.6$ & 248.7 & $\nabla 1$ & 3.30 \\
\hline 29 & $\mathrm{KT}$ & $7,272.0$ & 한국조선해양 & $7,212.9$ & 6.0 & $\triangle 1$ & 0.08 \\
\hline 30 & 한국조선해양 & $7,218.9$ & $\mathrm{KT}$ & $6,827.4$ & 444.6 & $\nabla 1$ & 6.51 \\
\hline 31 & 삼성전기 & $6,954.0$ & 삼성전기 & $6,767.8$ & 186.2 & - & 2.75 \\
\hline 32 & 강원랜드 & $6,503.8$ & 한온시스템 & $6,378.9$ & 0 & $\triangle 1$ & 0.00 \\
\hline 33 & 한온시스템 & $6,378.9$ & 웅진코웨이 & $6,210.8$ & 136.0 & $\triangle 1$ & 2.19 \\
\hline 34 & 웅진코웨이 & $6,346.8$ & 강원랜드 & $6,163.3$ & 340.5 & $\boldsymbol{\nabla} 2$ & 5.53 \\
\hline 35 & 현대글로비스 & $5,887.5$ & 현대글로비스 & $5,887.5$ & 0 & - & 0.00 \\
\hline
\end{tabular}


한국증권학회지 제49권 2호 (2020)

〈표 2-1〉 유가증권시장 시가총액 순위(계속)

\begin{tabular}{|c|c|c|c|c|c|c|c|}
\hline \multicolumn{3}{|c|}{ [1] 자사주 포함 시가총액 } & \multicolumn{2}{|c|}{ [2] 자사주 차감 시가총액 } & \multicolumn{3}{|c|}{ [1] - [2] 괴리 } \\
\hline 순위 & 회사명 & 시총 & 회사명 & 시총 & 시총 & 순위 & 괴리율 \\
\hline$\overline{36}$ & LG유플러스 & $5,675.9$ & LG유플러스 & $5,675.9$ & 0 & - & 0.00 \\
\hline 37 & 현대중공업지주 & $5,122.1$ & 현대제철 & $4,955.5$ & 82.1 & $\triangle 1$ & 1.66 \\
\hline 38 & 현대제철 & $5,037.6$ & LG디스플레이 & $4,866.3$ & 0 & $\triangle 1$ & 0.00 \\
\hline 39 & LG디스플레이 & $4,866.3$ & 현대건설 & $4,665.8$ & 0 & $\triangle 1$ & 0.00 \\
\hline 40 & 현대건설 & $4,665.8$ & 현대중공업지주 & $4,598.5$ & 523.6 & $\boldsymbol{\nabla} 3$ & 11.39 \\
\hline 41 & 아모레G & $4,650.6$ & GS & $4,570.5$ & 1 & $\triangle 1$ & 0.02 \\
\hline 42 & GS & $4,571.4$ & 아모레G & $4,300.5$ & 350.2 & $\boldsymbol{\nabla} 1$ & 8.14 \\
\hline 43 & 삼성중공업 & $4,365.9$ & 삼성중공업 & $4,186.0$ & 179.9 & - & 4.30 \\
\hline 44 & CJ제일제당 & $4,237.8$ & CJ제일제당 & $4,137.2$ & 100.6 & - & 2.43 \\
\hline 45 & 에스원 & $3,989.9$ & 휠라코리아 & $3,978.6$ & 0 & $\triangle 1$ & 0.00 \\
\hline 46 & 휠라코리아 & $3,978.6$ & 롯데쇼핑 & $3,760.0$ & 2.4 & $\triangle 2$ & 0.06 \\
\hline 47 & 한국가스공사 & $3,835.6$ & 한국타이어앤테크놀로지 & $3,734.2$ & 0.7 & $\triangle 2$ & 0.02 \\
\hline 48 & 롯데쇼핑 & $3,762.4$ & BGF리테일 & $3,688.2$ & 1.9 & $\triangle 2$ & 0.05 \\
\hline 49 & 한국타이어앤테크놀로지 & $3,734.8$ & 한국항공우주 & $3,665.1$ & 0 & $\triangle 2$ & 0.00 \\
\hline 50 & BGF리테일 & $3,690.1$ & 한국가스공사 & $3,641.3$ & 194.3 & $\boldsymbol{\nabla} 3$ & 5.34 \\
\hline
\end{tabular}

<표 2-1-1>은 삼성전자의 자사주 소각일(2018-12-12) 전후의 종가, 발행주식수, 자기 주식수, 시가총액을 보여주며, 여기서 발행주식수는 해당일의 상장주식수를 의미한다. 자기 주식이 전량 소각되자 발행주식수가 소각된 자기주식만큼 감소하였고 시가총액도 감소한 것을 알 수 있다. 즉, 과대평가된 시가총액 괴리율 $7.53 \%(=449,542,150 / 5,969,782,550)$ 이 자기주식 소각 직후에 사라짐을 알 수 있다. 이와 같은 자기 주식의 소각에 따른 시가총액 감소는 기계적인 것으로 정보측면에서는 사실상 아무 의미가 없는(non-event) 현상이다.

자사주 매입을 주주환원 정책으로 인식할 경우, 이에 대한 시장 반응 측정 시점을 언제로 봐야 하는지의 문제가 있다. 일반적으로는 공개매수(tender offer)의 경우 이사회에서 자사주 매입 결정을 하고 이를 공시한 시점으로 측정하고, 장내 매수(open market repurchase)는 실제 매입 시점5)으로 보는 것이 국내외 학계의 관행이다. 이러한 접근 방식은 자사주 매입시점 에서 시가총액에서 제외하는 해외의 경우에는 타당하나, 매입 자사주가 시가총액에 계속 포함되는 국내에는 타당성이 떨어진다고 볼 수 있다. 국내의 경우 매입 자사주가 추후 시장에서 재매각될 가능성을 고려하여 매입 시점에는 주주환원으로 인정하지 않고, 궁극적 으로 소각이 일어나야 주주환원으로 인정하는 경향이 있다. ${ }^{6)}$ 이러한 입장에 따르면, 시장 반응 측정 시점은 국내의 경우 자사주 매입 시점이 아닌 소각 시점이 보다 더 타당하다고 사료된다.

5) 이사회 결의 사실이 공시된 날의 다음 날부터 3 개월 이내에 증권시장에서 자기주식을 취득하여야 한다(자본시장법 제 165 조의 3 제 4 항, 동법 시행령 제 176 조의 2 제 3 항).

6) 과거 기업의 과다한 현금보유 축소 유도를 위해 시행되었던 기업소득환류세제(현행 상생협력 촉진세제)에 따르면 자사주 매입은 매입 이후 1 개월 이내에 소각될 경우에만 배당과 유사한 주주환원 으로 인정하여 과세 표준에서 제외한 바 있다. 
Effect of Including Treasury Shares in Market Capitalization, EPS, and PER

〈표 2-1-1〉 삼성전자 자사주 소각

이 표는 삼성전자의 자사주 소각 전후의 종가, 발행주식수, 자기주식수, 시가총액 시계열 자료를 보여준다. 발행주식수는 해당일의 상장주식수이고, 자기주식이 전량 소각됨으로써 발행주식수가 소각된 자기주식만큼 감소하였고 시가총액도 감소한 것을 알 수 있다.

\begin{tabular}{ccccc}
\hline 일시 & 종가(원) & 발행주식수(주) & 자기주식수(보통)(주) & 시가총액 (원) \\
\hline $2018-12-03$ & 43,250 & $6,419,324,700$ & $449,542,150$ & $277,635,793,000,000$ \\
$2018-12-04$ & 42,150 & $6,419,324,700$ & $449,542,150$ & $270,574,536,000,000$ \\
$2018-12-05$ & 41,450 & $6,419,324,700$ & $449,542,150$ & $266,081,009,000,000$ \\
$2018-12-06$ & 40,500 & $6,419,324,700$ & $449,542,150$ & $259,982,650,000,000$ \\
$2018-12-07$ & 40,950 & $6,419,324,700$ & $449,542,150$ & $262,871,346,000,000$ \\
$2018-12-10$ & 40,200 & $6,419,324,700$ & $449,542,150$ & $258,056,853,000,000$ \\
$2018-12-11$ & 40,250 & $6,419,324,700$ & $449,542,150$ & $258,377,819,000,000$ \\
$2018-12-12$ & 40,450 & $5,969,782,550$ & 0 & $241,477,704,000,000$ \\
$2018-12-13$ & 40,000 & $5,969,782,550$ & 0 & $238,791,302,000,000$ \\
$2018-12-14$ & 38,950 & $5,969,782,550$ & 0 & $232,523,030,000,000$ \\
$2018-12-17$ & 39,150 & $5,969,782,550$ & 0 & $233,716,987,000,000$ \\
$2018-12-18$ & 38,900 & $5,969,782,550$ & 0 & $232,224,541,000,000$ \\
$2018-12-19$ & 39,100 & $5,969,782,550$ & 0 & $233,418,498,000,000$ \\
$2018-12-20$ & 38,650 & $5,969,782,550$ & 0 & $230,732,096,000,000$ \\
$2018-12-21$ & 38,650 & $5,969,782,550$ & 0 & $230,732,096,000,000$ \\
$2018-12-24$ & 38,800 & $5,969,782,550$ & 0 & $231,627,563,000,000$ \\
$2018-12-26$ & 38,350 & $5,969,782,550$ & 0 & $228,941,161,000,000$ \\
$2018-12-27$ & 38,250 & $5,969,782,550$ & 0 & $228,344,183,000,000$ \\
$2018-12-28$ & 38,700 & $5,969,782,550$ & 0 & $231,030,585,000,000$ \\
\hline
\end{tabular}

[인사이트 기사참고] 2018 년 11월 30일 삼성전자는 이사회를 열고 보유 자사주 약 21조 5400억 원 어치(2018년 11월 29일 종가기준)를 전량 소각하기로 했다. 이는 보통주 4억 4,954만 2,150주(현 발행주식의 $7 \%$ )와 우선주 8,074만 2,300주(9\%)로 총 5억 3천만 주에 이르는 자기주식이다. https://m.post.naver.com/viewer/postView.nhn?volumeNo=17234734\&memberNo=29949587\&v Type=VERTICAL .

<표 2-2〉는 코스닥시장에 상장되어 있는 기업들의 2019년 7월 말 기준 1 위부터 50위 까지의 시가총액 순위를 나타낸다. 상위 50 개 기업의 시가총액 괴리율 평균은 $2.86 \%$, 중간 값은 $0.40 \%$, 왜도(skewness)는 2.35, 첨도(kurtosis)는 7.21 로 괴리율은 평균을 중심으로 오른쪽으로 꼬리가 두꺼운 분포를 갖는다. 코스닥시장의 시가총액 괴리율은 유가증권 시장에 비해 상대적으로 적게 나타나는데, 이는 매입 자사주를 활용한 지주회사 전환 또는 경영권 방어 등의 수요가 유가증권시장에 비해 상대적으로 더 약하기 때문으로 추정된다.

가장 괴리율이 높은 하림지주의 경우 자사주 제외 시가총액 대비 $24 \%$ 나 과대평가 되었고 자사주를 제외할 경우 시가총액 순위가 28 위에서 37 위로 9 단계 하락하게 된다. 유가증권 시장과 유사하게 코스닥 시장에서도 상위 50 개 기업의 시가총액 순위 변동은 평균적으로 1 단계임을 알 수 있다. 아울러 상위 50 개 기업 중에서 과대평가된 기업은 34 개 기업이고 이들의 괴리율 평균은 $4.21 \%$, 중간값은 $2.69 \%$, 왜도(skewness)는 1.91 , 첨도(kurtosis)는 4.86로 역시 평균을 중심으로 오른쪽으로 꼬리가 두꺼운 분포를 갖는다. 
한국증권학회지 제49권 2호 (2020)

〈표 2-2〉 코스닥시장 시가총액 순위

이 표는 코스닥시장에 상장되어 있는 기업들의 2019년 7월 말 기준 1 위부터 50 위까지의 시가총액 순위를 나타낸다. [1]은 자사주를 포함한 시가총액(=종가 $\times$ 발행주식수)이고, [2]는 발행주식수에서 자사주를 차감한 시가총액(=종가 $\times$ (발행주식수-자기주식수))이다. [1]-[2] 괴리에서는 자사주 포함 여부에 따른 시가총액의 금액 차이와 시가총액 순위의 변화, 그리고 시가총액 괴리율을 보여주며, [2]열에 나열된 회사기준으로 계산하였다. 단위는 십억 원이다.

(단위: 십억 원)

\begin{tabular}{|c|c|c|c|c|c|c|c|}
\hline & \multicolumn{2}{|c|}{ [1] 자사주 포함 시가총액 } & \multicolumn{2}{|c|}{ [2] 자사주 차감 시가총액 } & \multicolumn{3}{|c|}{ [1] - [2] 괴리 } \\
\hline 순위 & 회사명 & 시총 & 회사명 & 시총 & 시총 & 순위 & 괴리율 \\
\hline 1 & 셀트리온헬스케어 & $6,356.8$ & 셀트리온헬스케어 & $6,287.5$ & 69.2 & - & 1.10 \\
\hline 2 & CJ ENM & $3,537.2$ & CJ ENM & $3,166.9$ & 370.2 & - & 11.69 \\
\hline 3 & 헬릭스미스 & $2,894.5$ & 헬릭스미스 & $2,894.5$ & 0 & - & 0.00 \\
\hline 4 & 메디톡스 & $2,281.3$ & 신라젠 & $2,216.8$ & 0 & $\triangle 2$ & 0.00 \\
\hline 5 & 펄어비스 & $2,264.4$ & 메디톡스 & $2,128.1$ & 153.2 & $\nabla 1$ & 7.20 \\
\hline 6 & 신라젠 & $2,216.8$ & 펄어비스 & $2,112.1$ & 152.4 & $\boldsymbol{\nabla} 1$ & 7.21 \\
\hline 7 & 케이엠더블유 & $2,057.6$ & 케이엠더블유 & $2,057.6$ & 0 & - & 0.00 \\
\hline 8 & 휴젤 & $1,983.5$ & 휴젤 & $1,890.6$ & 92.9 & - & 4.92 \\
\hline 9 & SK머티리얼즈 & $1,826.9$ & 스튜디오드래곤 & $1,666.3$ & 0 & $\triangle 1$ & 0.00 \\
\hline 10 & 스튜디오드래곤 & $1,666.3$ & SK머티리얼즈 & $1,643.3$ & 183.6 & $\boldsymbol{\nabla} 1$ & 11.17 \\
\hline 11 & 파라다이스 & $1,427.8$ & 파라다이스 & $1,337.4$ & 90.4 & - & 6.76 \\
\hline 12 & 에스에프에이 & $1,281.9$ & 코미팜 & $1,209.2$ & 5.4 & $\triangle 2$ & 0.45 \\
\hline 13 & 솔브레인 & $1,216.1$ & 에스에프에이 & $1,196.3$ & 85.7 & $\nabla 1$ & 7.16 \\
\hline 14 & 코미팜 & $1,214.6$ & 솔브레인 & $1,179.4$ & 36.8 & $\nabla 1$ & 3.12 \\
\hline 15 & 셀트리온제약 & $1,175.6$ & 셀트리온제약 & $1,174.8$ & 0.8 & - & 0.07 \\
\hline 16 & 원익IPS & $1,173.1$ & 원익IPS & $1,172.8$ & 0.3 & - & 0.03 \\
\hline 17 & 제넥신 & $1,143.4$ & 제넥신 & $1,143.4$ & 0 & - & 0.00 \\
\hline 18 & 에코프로비엠 & $1,142.3$ & 에코프로비엠 & $1,138.2$ & 4 & - & 0.35 \\
\hline 19 & 컴투스 & $1,125.8$ & 고영 & $1,108.3$ & 17.3 & $\triangle 1$ & 1.56 \\
\hline 20 & 고영 & $1,125.6$ & 메지온 & $1,072.3$ & 0 & $\triangle 2$ & 0.00 \\
\hline 21 & GS홈쇼핑 & 1,077.6 & 에이치엘비 & $1,068.5$ & 2.6 & $\triangle 2$ & 0.25 \\
\hline 22 & 메지온 & $1,072.3$ & 컴투스 & $1,064.8$ & 61 & $\boldsymbol{\nabla} 3$ & 5.73 \\
\hline 23 & 에이치엘비 & $1,071.1$ & 상상인 & 984.8 & 9.3 & $\triangle 1$ & 0.94 \\
\hline 24 & 상상인 & 994.1 & GS홈쇼핑 & 984 & 93.6 & $\nabla 3$ & 9.51 \\
\hline 25 & 아난티 & 956.6 & 아난티 & 956.6 & 0 & - & 0.00 \\
\hline 26 & 오스템임플란트 & 955.7 & 이오테크닉스 & 933.6 & 0.2 & $\triangle 1$ & 0.02 \\
\hline 27 & 이오테크닉스 & 933.8 & SKC코오롱PI & 925 & 0 & $\triangle 2$ & 0.00 \\
\hline 28 & 하림지주 & 932.1 & 오스템임플란트 & 924.3 & 31.4 & $\boldsymbol{\nabla} 2$ & 3.40 \\
\hline 29 & $\mathrm{SKC}$ 코오롱PI & 925 & NICE평가정보 & 902.7 & 14.1 & $\triangle 1$ & 1.56 \\
\hline 30 & NICE평가정보 & 916.8 & 클래시스 & 880 & 0 & $\triangle 1$ & 0.00 \\
\hline 31 & 클래시스 & 880 & 에이비엘바이오 & 872.1 & 0 & $\triangle 1$ & 0.00 \\
\hline 32 & 에이비엘바이오 & 872.1 & 리노공업 & 817.7 & 5.4 & $\triangle 1$ & 0.65 \\
\hline 33 & 리노공업 & 823.1 & 콜마비앤에이치 & 812.4 & 0.1 & $\triangle 2$ & 0.01 \\
\hline 34 & 케어젠 & 821.8 & 서울반도체 & 780.6 & 12.4 & $\triangle 2$ & 1.58 \\
\hline 35 & 콜마비앤에이치 & 812.4 & 케어젠 & 761.6 & 60.2 & $\boldsymbol{\nabla} 1$ & 7.91 \\
\hline 36 & 서울반도체 & 793 & 에스엠 & 758.2 & 1.1 & $\triangle 1$ & 0.14 \\
\hline
\end{tabular}


Effect of Including Treasury Shares in Market Capitalization, EPS, and PER

〈표 2-2〉코스닥시장 시가총액 순위(계속)

\begin{tabular}{|c|c|c|c|c|c|c|c|}
\hline & \multicolumn{2}{|c|}{ [1] 자사주 포함 시가총액 } & \multicolumn{2}{|c|}{ [2] 자사주 차감 시가총액 } & \multicolumn{3}{|c|}{ [1] - [2] 괴리 } \\
\hline 순위 & 회사명 & 시총 & 회사명 & 시총 & 시총 & 순위 & 괴리율 \\
\hline 37 & 에스엠 & 759.2 & 하림지주 & 752.1 & 180 & $\nabla 9$ & 23.94 \\
\hline 38 & 파트론 & 755.5 & 포스코 ICT & 746.1 & 1.1 & $\triangle 1$ & 0.15 \\
\hline 39 & 포스코 ICT & 747.3 & 동진쎄미켐 & 737.8 & 0 & $\triangle 1$ & 0.00 \\
\hline 40 & 동진쎄미켐 & 737.8 & 차바이오텍 & 732.1 & 0 & $\triangle 1$ & 0.00 \\
\hline 41 & 차바이오텍 & 732.1 & 파트론 & 717.1 & 38.4 & $\nabla 3$ & 5.35 \\
\hline 42 & JYP Ent. & 717 & 삼천당제약 & 682.8 & 22.3 & $\triangle 1$ & 3.27 \\
\hline 43 & 삼천당제약 & 705.2 & RFHIC & 672.8 & 0 & $\triangle 3$ & 0.00 \\
\hline 44 & 엘앤에프 & 692 & JYP Ent. & 668.5 & 48.5 & $\boldsymbol{\nabla} 2$ & 7.25 \\
\hline 45 & 네패스 & 681.4 & 네패스 & 666.4 & 15 & - & 2.25 \\
\hline 46 & RFHIC & 672.8 & 티씨케이 & 637.5 & 0 & $\triangle 2$ & 0.00 \\
\hline 47 & 아프리카TV & 666.7 & 천보 & 632 & 0 & $\triangle 2$ & 0.00 \\
\hline 48 & 티씨케이 & 637.5 & 매일유업 & 629.6 & 0.2 & $\triangle 2$ & 0.04 \\
\hline 49 & 천보 & 632 & 아프리카TV & 627.2 & 39.5 & $\boldsymbol{\nabla} 2$ & 6.29 \\
\hline 50 & 매일유업 & 629.8 & 국일제지 & 621.7 & 0 & $\triangle 1$ & 0.00 \\
\hline
\end{tabular}

\subsection{3 시가총액 산업별 특성}

<표 3-1>과 <그림 2-1>은 2003년부터 2019년까지 유가증권시장과 코스닥시장에 상장된 기업들의 산업별 시가총액의 합을 자사주 포함과 차감 경우로 구분하여 변화추이를 보여 준다. 패널 $\mathrm{A}$ 는 전체 표본에 대한 분석이고 패널 $\mathrm{B}$ 는 자사주를 보유하고 있는 부표본에 대한 분석이다. 자사주 보유비중은 산업별로 차이가 있고 숙박 및 음식업이 $28.6 \%$ 로 가장 낮고 교육 서비스업이 $82.4 \%$ 로 가장 높으며 평균은 약 $64 \%$ 이다.

시가총액 규모에서 제조업은 전체 업종의 $66 \%(=10,109 / 15,336)$ 로 비중이 월등히 크고 괴리율이 전체 표본에서는 $5.54 \%$, 자사주 보유 표본에서는 $7 \%$ 로 공시된 시가총액도 과대 평가되어 있음을 알 수 있다. 특히 정보 통신업 및 전문, 과학 및 기술 서비업, 사업시설 관리업의 괴리율이 전체 표본에서는 $7 \%$ 이상, 자사주 보유표본에서는 $8 \%$ 이상으로 비교적 높게 나타나는 데, 이들 업종은 향후 지주회사 전환시 자사주를 활용하기 위해 상대적으로 많은 자사주를 보유하고 있는 것으로 추정해 볼 수 있다.

<표 3-2>과 <그림 2-2〉는 제조업 산업별 시가총액의 합을 자사주 포함과 차감 경우로 구분하여 변화추이를 보여준다. 전자부품, 컴퓨터, 영상, 음향, 통신장비 제조업의 제조업 중에서 비중은 $37 \%(=3,760 / 10,109)$ 이고 괴리율이 전체표본에서는 $7.45 \%$, 자사주 보유 표본에서는 $9.89 \%$ 로 제조업 평균 괴리율 $5.54 \%$ (보유 표본 $7.35 \%$ )보다 높다. 특히 가죽, 가방 및 신발 제조업과 목재 및 나무제품 제조업은 시기총액 규모는 작지만 괴리율(전체/ 보유)이 각각 $18.88 \% / 38.84 \%, 14.67 \% / 18.34 \%$ 로 매우 과대평가되어 있어서 PER를 이용한 $\mathrm{IPO}$ 공모가격 산정에 주의를 요한다고 할 수 있다. 아울러 담배 제조업은 자사주를 보유한 기업이 $100 \%$ 인 것으로 조사되었다. 


\section{〈표 3-1〉 산업별 시가총액 현황}

이 표는 2003년부터 2019년까지 유가증권시장과 코스닥시장에 상장된 기업들의 산업별 시가총액의 총합을 나타낸다. 패널A는 전체 표본에 대한 분석이고, 패널 $\mathrm{B}$ 는 자사주를 보유하고 있는 부표본에 대한 분석이다. 산업분류는 한국표준산업분류 10 차 대분류 기준이며, 시가총액은 해당 년도 말 (종가 $\times$ (발행주식수-자기주식수))로 구하였고 2019년은 7월 말 기준으로 계산하였다. [1]은 자사주를 포함한 시가총액(= 종가 $\times$ 발행주식수 $)$ 이고, [2]는 발행주식수에서 시가총액을 차감하여 산출한 시가 총액 $(=$ 종가 $\times($ 발행주식수-자기주식수 $)$ 이다. [1]-[2]괴리는 두 경우의 시가총액의 차이를 나타내고 괴리율은 자사주를 차감한 시가총액 대비 두 경우의 시가총액 차이를 나타내며, 자사주 보유비중은 전체 표본 중에 자사주를 보유한 기업의 비중을 의미한다. 단위는 조 원이다.

패널 $\mathrm{A}$ : 전체표본

(단위: 조 원)

\begin{tabular}{|c|c|c|c|c|c|c|c|}
\hline $\begin{array}{l}\text { 산업 } \\
\text { 코드 }\end{array}$ & 산업명 & $\begin{array}{l}\text { 관측 } \\
\text { 치수 }\end{array}$ & $\begin{array}{c}{[1]} \\
\text { 자사주포함 }\end{array}$ & $\begin{array}{cc}\text { [2] } & {[1} \\
\text { 자사주차감 } & \end{array}$ & $\begin{array}{c}1]-[2] \\
\text { 괴리 }\end{array}$ & 괴리율 & $\begin{array}{c}\text { 자사주 } \\
\text { 보유비중 }\end{array}$ \\
\hline $\mathrm{A}$ & 농업, 임업 및 어업 & 80 & 18.0 & 17.9 & 0.1 & $0.41 \%$ & $43.75 \%$ \\
\hline $\mathrm{B}$ & 광업 & 64 & 6.5 & 6.5 & 0.0 & $0.46 \%$ & $59.38 \%$ \\
\hline $\mathrm{C}$ & 제조업 & 18,265 & $10,669.3$ & $10,109.0$ & 560.3 & $5.54 \%$ & $66.52 \%$ \\
\hline $\mathrm{D}$ & 전기, 가스 및 공기조절 공급업 & 180 & 489.3 & 475.1 & 14.2 & $2.99 \%$ & $82.22 \%$ \\
\hline $\mathrm{E}$ & 수도, 하수 및 폐기물 처리업 & 103 & 9.3 & 9.2 & 0.1 & $0.65 \%$ & $70.87 \%$ \\
\hline $\mathrm{F}$ & 건설업 & 1,041 & 418.3 & 412.4 & 5.9 & $1.42 \%$ & $59.37 \%$ \\
\hline G & 도매 및 소매업 & 2,361 & $1,123.4$ & $1,081.9$ & 41.5 & $3.84 \%$ & $65.86 \%$ \\
\hline $\mathrm{H}$ & 운수 및 창고업 & 416 & 318.8 & 307.3 & 11.5 & $3.75 \%$ & $74.28 \%$ \\
\hline I & 숙박 및 음식점 & 28 & 7.7 & 7.7 & 0.0 & $0.07 \%$ & $28.57 \%$ \\
\hline $\mathrm{J}$ & 정보 통신업 & 3,254 & $1,550.9$ & $1,449.2$ & 101.7 & $7.02 \%$ & $68.35 \%$ \\
\hline $\mathrm{L}$ & 부동산업 및 임대업 & 56 & 6.3 & 6.2 & 0.1 & $0.99 \%$ & $35.71 \%$ \\
\hline M & 전문, 과학 및 기술 서비스업 & 1,685 & $1,243.9$ & $1,155.2$ & 88.7 & $7.68 \%$ & $72.28 \%$ \\
\hline $\mathrm{N}$ & 사업시설관리 & 267 & 79.9 & 74.4 & 5.5 & $7.39 \%$ & $76.78 \%$ \\
\hline $\mathrm{P}$ & 교육 서비스업 & 165 & 26.6 & 25.4 & 1.2 & $4.78 \%$ & $82.42 \%$ \\
\hline $\mathrm{R}$ & 예술, 스포츠 및 여가서비스업 & 175 & 141.3 & 135.7 & 5.6 & $4.10 \%$ & $60.57 \%$ \\
\hline $\mathrm{S}$ & 협회, 단체 및 개인서비스업 & 17 & 64.7 & 62.8 & 1.9 & $2.95 \%$ & $82.35 \%$ \\
\hline \multicolumn{8}{|c|}{ 패널 $\mathrm{B}$ : 자사주 보유표본 } \\
\hline $\begin{array}{l}\text { 산업 } \\
\text { 코드 }\end{array}$ & 업명 & $\begin{array}{l}\text { 관측 } \\
\text { 치수 }\end{array}$ & $\begin{array}{c}\text { [1] } \\
\text { 자사주포함 }\end{array}$ & $\begin{array}{c}{[2]} \\
\text { 자사주차감 }\end{array}$ & & $\begin{array}{l}]-[2] \\
\text { 괴리 } \\
\end{array}$ & 괴리율 \\
\hline $\mathrm{A}$ & 농업, 임업 및 어업 & 35 & 4.4 & 4.3 & & 0.1 & $1.72 \%$ \\
\hline $\mathrm{B}$ & 광업 & 38 & 4 & 4 & & 0.0 & $0.75 \%$ \\
\hline $\mathrm{C}$ & 제조업 & 12,149 & $8,561.8$ & $8,001.4$ & & 60.3 & $7.00 \%$ \\
\hline $\mathrm{D}$ & 전기, 가스 및 공기조절 공급업 & 148 & 328 & 313.8 & & 14.2 & $4.53 \%$ \\
\hline $\mathrm{E}$ & 수도, 하수 및 폐기물 처리업 & 73 & 5.7 & 5.6 & & 0.1 & $1.07 \%$ \\
\hline $\mathrm{F}$ & 건설업 & 618 & 188.8 & 182.9 & & 5.9 & $3.20 \%$ \\
\hline G & 도매 및 소매업 & 1,555 & 739.2 & 697.7 & & 41.5 & $5.95 \%$ \\
\hline $\mathrm{H}$ & 운수 및 창고업 & 309 & 174.7 & 163.2 & & 11.5 & $7.06 \%$ \\
\hline I & 숙박 및 음식점 & 8 & 2.6 & 2.6 & & 0.0 & $0.22 \%$ \\
\hline $\mathrm{J}$ & 정보 통신업 & 2,224 & $1,377.9$ & $1,276.2$ & & 01.7 & $7.97 \%$ \\
\hline $\mathrm{L}$ & 부동산업 및 임대업 & 20 & 2.1 & 2.1 & & 0.1 & $2.99 \%$ \\
\hline M & 전문, 과학 및 기술 서비스업 & 1,218 & $1,091.1$ & $1,002.4$ & & 88.7 & $8.85 \%$ \\
\hline $\mathrm{N}$ & 사업시설관리 & 205 & 71.2 & 65.7 & & 5.5 & $8.36 \%$ \\
\hline $\mathrm{P}$ & 교육 서비스업 & 136 & 21.4 & 20.2 & & 1.2 & $6.00 \%$ \\
\hline $\mathrm{R}$ & 예술, 스포츠 및 여가서비스업 & 106 & 119.5 & 114 & & 5.6 & $4.88 \%$ \\
\hline $\mathrm{S}$ & 협회, 단체 및 개인서비스업 & 14 & 58.6 & 56.7 & & 1.9 & $3.27 \%$ \\
\hline
\end{tabular}


Effect of Including Treasury Shares in Market Capitalization, EPS, and PER

〈그림 2-1〉 자사주 포함 여부에 따른 산업별 시가총액 괴리

이 그림은 2003년부터 2019년까지 유가증권시장과 코스닥시장에 상장된 기업들의 산업별 시가총액의 합과 괴리율을 그래프로 나타낸다. 산업분류는 한국표준산업분류 10 차 대분류 기준이며, 시가총액은 해당 년도 말 (보통주 종가) $\times$ (발행주식수)로 구하였고 2019년은 7월 말 기준으로 계산하였다. [1]은 자사주를 포함한 시가총액이고, [2]는 발행주식수에서 시가총액을 차감하여 산출한 시가총액이며 단위는 조 원이다. 괴리율은 자사주를 차감한 시가총액 대비 두 그룹의 시가총액 차이를 나타내며, 단위는 퍼센트 $(\%)$ 이다.

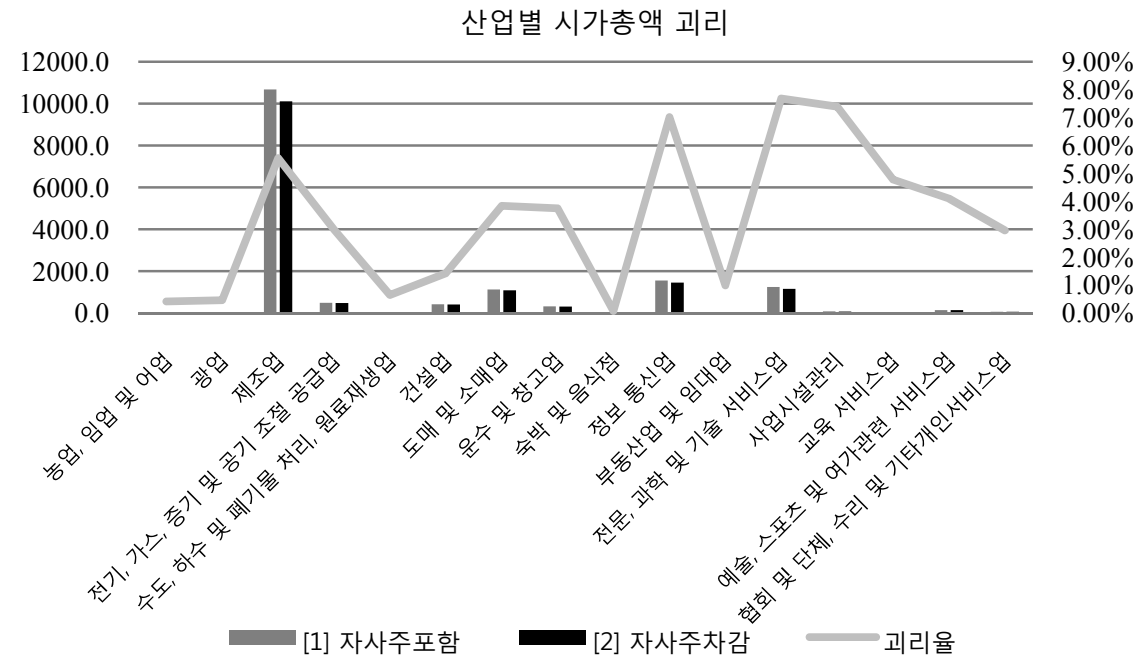

〈표 3-2〉 산업별 시가총액 현황(제조업)

이 표는 2003년부터 2019년까지 유가증권시장과 코스닥시장에 상장된 기업들의 산업별 시가총액의 합을 나타낸다. 패널 $\mathrm{A}$ 는 전체 표본에 대한 분석이고, 패널 $\mathrm{B}$ 는 자사주를 보유하고 있는 부표본에 대한 분석이다. 산업분류는 한국표준산업분류 10 차 대분류 중에서 제조업만 분리하여 세분화된 중분류를 보여준다. 시가총액은 해당 년도 말 (보통주 종가) $\times$ (발행주식수)로 구하였고 2019년은 7월 말 기준으로 계산하였다. [1]은 자사주를 포함한 시가총액(=종가 $\times$ 발행주식수)이고, [2]는 발행주식수에서 자기주식수를 차감하여 산출한 시가총액(=종가 $\times($ 발행주식수-자기주식수 $)$ 이다. [1]-[2]괴리는 두 경우의 시가총액의 차이를 나타내고 괴리율은 자사주를 차감한 시가총액 대비 두 경우의 시가총액 차이를 나타내며, 자사주 보유비중은 전체 표본 중에 자사주를 보유한 기업의 비중을 의미한다. 단위는 조 원이다.

패널 $\mathrm{A}$ : 전체표본

(단위: 조 원)

\begin{tabular}{|c|c|c|c|c|c|c|c|}
\hline $\begin{array}{l}\text { 산업 } \\
\text { 코드 }\end{array}$ & 산업명 & $\begin{array}{l}\text { 관측 } \\
\text { 치수 }\end{array}$ & $\begin{array}{c}1] \\
\text { 자사주 } \\
\text { 포함 }\end{array}$ & $\begin{array}{c}{[2]} \\
\text { 자사주 } \\
\text { 차감 }\end{array}$ & $\begin{array}{c}\text { [1]-[2] } \\
\text { 괴리 }\end{array}$ & 괴리율 & $\begin{array}{c}\text { 자사주 } \\
\text { 보유 } \\
\text { 비중 }\end{array}$ \\
\hline 10 & 식료품 제조업 & 78 & 244.3 & 236.8 & 7. & $3.14 \%$ & $\overline{66.20 \%}$ \\
\hline 11 & 음료 제조업 & 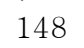 & 64.0 & 63.0 & 1.0 & & $60.14 \%$ \\
\hline 12 & 담배 제조업 &  & 180.3 & 164.9 & 15 & $9.34 \%$ & $100.00 \%$ \\
\hline 13 & 섬유제품 제조업; 의복제외 & 231 & 14.8 & 14.1 & 0.6 & $4.44 \%$ & $78.79 \%$ \\
\hline 14 & 의복, 의복 액세서리 및 모피제품 제조업 & 412 & 65.9 & 64.0 & 1.9 & $2.91 \%$ & $63.35 \%$ \\
\hline 15 & 가죽, 가방 및 신발 제조업 & 74 & 8.9 & 7.5 & 1.4 & $18.88 \%$ & $70.27 \%$ \\
\hline 16 & 목재 및 나무제품 제조업; 가구 제외 & 59 & 8.0 & 7.0 & 1.0 & $14.67 \%$ & $72.88 \%$ \\
\hline 17 & 펄프, 종이 및 종이제품 제조업 & 441 & 35.4 & 34.7 & 0.7 & $2.03 \%$ & $54.65 \%$ \\
\hline
\end{tabular}


한국증권학회지 제49권 2호 (2020)

〈표 3-2〉 산업별 시가총액 현황(제조업)(계속)

\begin{tabular}{|c|c|c|c|c|c|c|c|}
\hline $\begin{array}{l}\text { 산업 } \\
\text { 코드 }\end{array}$ & 산업명 & $\begin{array}{l}\text { 관측 } \\
\text { 치수 }\end{array}$ & $\begin{array}{c}\text { [1] } \\
\text { 자사주 } \\
\text { 포함 }\end{array}$ & $\begin{array}{c}\text { [2] } \\
\text { 자사주 } \\
\text { 차감 }\end{array}$ & $\begin{array}{c}\text { [1]-[2] } \\
\text { 괴리 }\end{array}$ & 괴리율 & $\begin{array}{c}\text { 자사주 } \\
\text { 보유 } \\
\text { 비중 }\end{array}$ \\
\hline & 인쇄 및 기록매체 복제업 & 74 & 14.9 & 14.8 & 0.1 & $0.59 \%$ & $68.92 \%$ \\
\hline & 코크스, 연탄 및 석유정제품 제조업 & 101 & 353.5 & 341.7 & 11.7 & $3.43 \%$ & $61.39 \%$ \\
\hline 20 & 화학물질 및 제품 제조업; 의약품 제외 & 1,750 & $1,322.5$ & $1,277.0$ & 45.5 & $3.57 \%$ & $67.71 \%$ \\
\hline 21 & 의료용 물질 및 의약품 제조업 & 1,457 & 613.9 & 599.9 & 14.0 & $2.33 \%$ & $66.92 \%$ \\
\hline 22 & 고무 및 플라스틱제품 제조업 & 704 & 161.6 & 160.4 & 1.2 & $0.78 \%$ & $61.79 \%$ \\
\hline 23 & 비금속 광물제품 제조업 & 535 & 118.9 & 114.9 & 4.0 & $3.46 \%$ & $53.46 \%$ \\
\hline 24 & 1차 금속 제조업 & 1,250 & 861.3 & 798.1 & 63.2 & $7.91 \%$ & $62.96 \%$ \\
\hline 25 & 금속가공제품 제조업; 기계, 가구 제외 & 633 & 65.4 & 64.1 & 1.3 & $1.97 \%$ & $67.14 \%$ \\
\hline 26 & 전자부품, 컴퓨터, 영상, 음향, 통신장비 & 4,126 & $4,040.2$ & $3,760.1$ & 280.1 & $7.45 \%$ & $69.83 \%$ \\
\hline 27 & 의료, 정밀, 광학기기 및 시계 제조업 & 733 & 79.7 & 77.8 & 1.9 & $2.44 \%$ & $67.12 \%$ \\
\hline 28 & 전기장비 제조업 & 859 & 257.9 & 247.1 & 10.8 & $4.35 \%$ & $72.99 \%$ \\
\hline 29 & 기타 기계 및 장비 제조업 & 2,054 & 409.0 & 393.3 & 15.7 & $4.00 \%$ & $64.56 \%$ \\
\hline 30 & 자동차 및 트레일러 제조업 & 1,284 & $1,181.0$ & $1,145.2$ & 35.8 & $3.12 \%$ & $64.49 \%$ \\
\hline 31 & 기타 운송장비 제조업 & 282 & 541.9 & 498.0 & 44.0 & $8.83 \%$ & $73.40 \%$ \\
\hline 32 & 가구 제조업 & 121 & 16.1 & 14.7 & 1.3 & $9.14 \%$ & $80.17 \%$ \\
\hline 33 & 기타 제품 제조업 & 136 & 10.2 & 9.9 & 0.3 & $3.01 \%$ & $59.56 \%$ \\
\hline
\end{tabular}

패널 $\mathrm{B}$ : 자사주 보유표본

\begin{tabular}{|c|c|c|c|c|c|c|}
\hline $\begin{array}{l}\text { 산업 } \\
\text { 코드 }\end{array}$ & 산업명 & $\begin{array}{l}\text { 관측 } \\
\text { 치수 }\end{array}$ & $\begin{array}{c}\text { [1] } \\
\text { 자사주 } \\
\text { 포함 }\end{array}$ & $\begin{array}{c}\text { [2] } \\
\text { 자사주 } \\
\text { 차감 }\end{array}$ & $\begin{array}{c}\text { [1]-[2] } \\
\text { 괴리 }\end{array}$ & 괴리율 \\
\hline 10 & 식료품 제조업 & 519 & 204.6 & 197.2 & 7.4 & $3.77 \%$ \\
\hline 11 & 음료 제조업 & 89 & 41.1 & 40.1 & 1 & $2.56 \%$ \\
\hline 12 & 담배 제조업 & 17 & 180.3 & 164.9 & 15.4 & $9.34 \%$ \\
\hline 13 & 섬유제품 제조업; 의복제외 & 182 & 13 & 12.4 & 0.6 & $5.08 \%$ \\
\hline 14 & 의복, 의복 액세서리 및 모피제품 제조업 & 261 & 35.1 & 33.2 & 1.9 & $5.61 \%$ \\
\hline 15 & 가죽, 가방 및 신발 제조업 & 52 & 5.1 & 3.7 & 1.4 & $38.84 \%$ \\
\hline 16 & 목재 및 나무제품 제조업; 가구 제외 & 43 & 6.6 & 5.6 & 1 & $18.34 \%$ \\
\hline 17 & 펄프, 종이 및 종이제품 제조업 & 241 & 22.2 & 21.5 & 0.7 & $3.27 \%$ \\
\hline 18 & 인쇄 및 기록매체 복제업 & 51 & 2.8 & 2.7 & 0.1 & $3.23 \%$ \\
\hline 19 & 코크스, 연탄 및 석유정제품 제조업 & 62 & 225 & 213.3 & 11.7 & $5.50 \%$ \\
\hline 20 & 화학물질 및 제품 제조업; 의약품 제외 & 1,185 & $1,090.9$ & $1,045.3$ & 45.5 & $4.36 \%$ \\
\hline 21 & 의료용 물질 및 의약품 제조업 & 975 & 459.7 & 445.7 & 14 & $3.14 \%$ \\
\hline 22 & 고무 및 플라스틱제품 제조업 & 435 & 108.5 & 107.2 & 1.2 & $1.16 \%$ \\
\hline 23 & 비금속 광물제품 제조업 & 286 & 69.3 & 65.4 & 4 & $6.08 \%$ \\
\hline 24 & 1차 금속 제조업 & 787 & 816.8 & 753.7 & 63.2 & $8.38 \%$ \\
\hline 25 & 금속가공제품 제조업; 기계, 가구 제외 & 425 & 36.5 & 35.2 & 1.3 & $3.58 \%$ \\
\hline 26 & 전자부품, 컴퓨터, 영상, 음향, 통신장비 & 2,881 & $3,113.1$ & 2833 & 280.1 & $9.89 \%$ \\
\hline 27 & 의료, 정밀, 광학기기 및 시계 제조업 & 492 & 54.7 & 52.8 & 1.9 & $3.60 \%$ \\
\hline 28 & 전기장비 제조업 & 627 & 232.7 & 221.9 & 10.8 & $4.85 \%$ \\
\hline 29 & 기타 기계 및 장비 제조업 & 1,326 & 233.2 & 217.4 & 15.7 & $7.24 \%$ \\
\hline 30 & 자동차 및 트레일러 제조업 & 828 & $1,119.9$ & $1,084.1$ & 35.8 & $3.30 \%$ \\
\hline 31 & 기타 운송장비 제조업 & 207 & 469.7 & 425.7 & 44 & $10.32 \%$ \\
\hline 32 & 가구 제조업 & 97 & 14.3 & 13 & 1.3 & $10.36 \%$ \\
\hline 33 & 기타 제품 제조업 & 81 & 6.8 & 6.5 & 0.3 & $4.56 \%$ \\
\hline
\end{tabular}


Effect of Including Treasury Shares in Market Capitalization, EPS, and PER

〈그림 2-2〉 자사주 포함 여부에 따른 제조업 산업별 시가총액 괴리

이 그림은 2003년부터 2019년까지 유가증권시장과 코스닥시장에 상장된 기업들의 산업별 시가 총액의 합과 괴리율을 그래프로 나타낸다. 산업분류는 한국표준산업분류 10차 대분류 기준이며, 시가 총액은 해당 년도 말 (보통주 종가)×(발행주식수)로 구하였고 2019년은 7월 말 기준으로 계산하였다. [1]은 자사주를 포함한 시가총액 $=$ 종가 $\times$ 발행주식수 $)$ 이고, [2]는 발행주식수에서 시가총액을 차감하여 산출한 시가총액 $(=$ 종가 $\times($ 발행주식수-자기주식수 $)$ 이며 단위는 조 원이다. 괴리율은 자사주를 차감한 시가총액 대비 두 그룹의 시가총액 차이를 나타내며, 단위는 퍼센트(\%)이다.
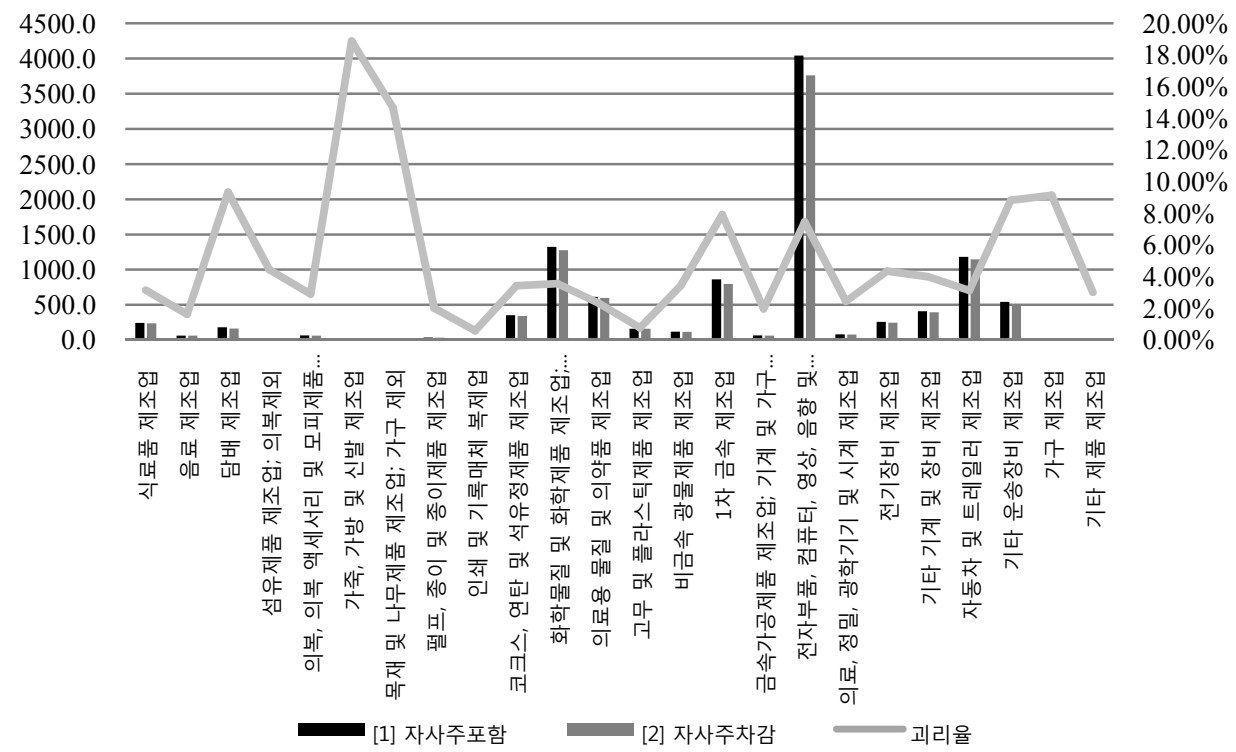

\section{2 주당 순이익(EPS)}

<표 4>는 2003년부터 2019년까지 유가증권시장과 코스닥시장에 상장된 기업들의 자사주 포함 여부에 따른 연도별 평균 $\mathrm{EPS}$, 수정EPS를 나타낸다. EPS와 수정EPS의 계산에서 분자는 당기순이익으로 같고, 차이는 분모에서 평균주식수 혹은 수정평균 주식수 사용여부에 기인한다. 패널 $\mathrm{A}$ 는 전체 표본에 대한 분석이고 패널 $\mathrm{B}$ 는 자사주를 보유하고 있는 부표본에 대한 분석이다. 패널 A-1/A-2 혹은 B-1/B-2의 구분은 당기순이익 자료의 차이로 1 은 연결재무제표의 지배주주순이익을 사용하였고, 2 는 별도재무제표의 당기순이익을 사용하였다. 아울러 기업의 규모를 고려하기 위해서 시가총액으로 가중평균한 값과 동일가중 평균값 (단순 평균)을 동시에 제공한다. EPS와 수정EPS의 괴리율이 같음을 알 수 있는데, 이는 이전 소절(2.2.1)의 괴리율 계산을 이용하여 검증할 수 있다. 즉, EPS의 괴리율은 변수 정의에 따라서 -ts/shr로 식이 정리되고, 수정평균발행주식수는 평균발행주식수에 주식조정계수를 적용한 주식수를 의미하기 때문에 분모 및 분자에 적용된 주식조정계수가 상쇄되어 $\mathrm{EPS}$ 와 수정EPS의 괴리율이 같게 된다. 


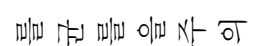

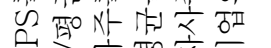

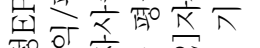
रु०

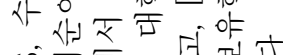

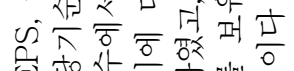

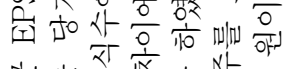

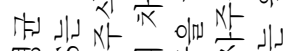
प्र० की

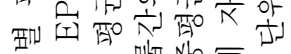
H

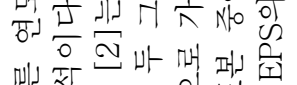



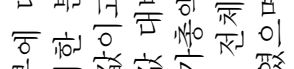

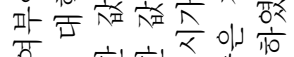
एक 宊



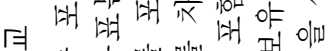

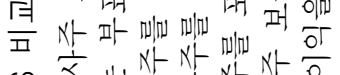

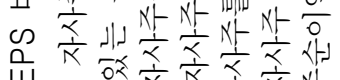
गा गण

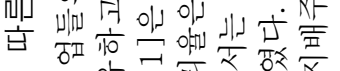



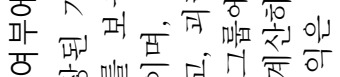

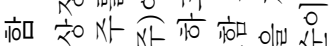

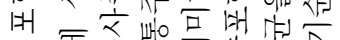

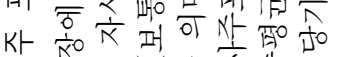

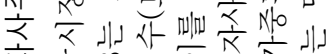



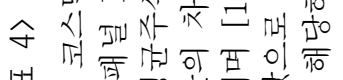
明

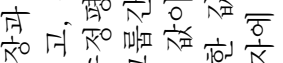

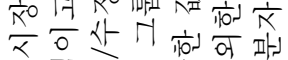

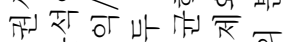

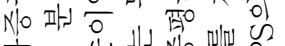

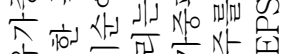

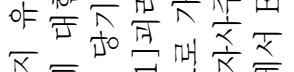

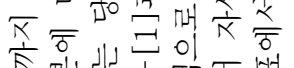

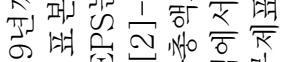

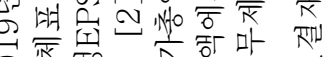

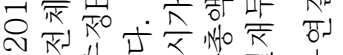
Ш山

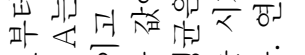



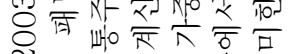

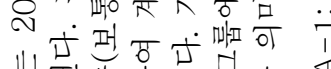

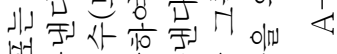

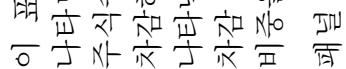

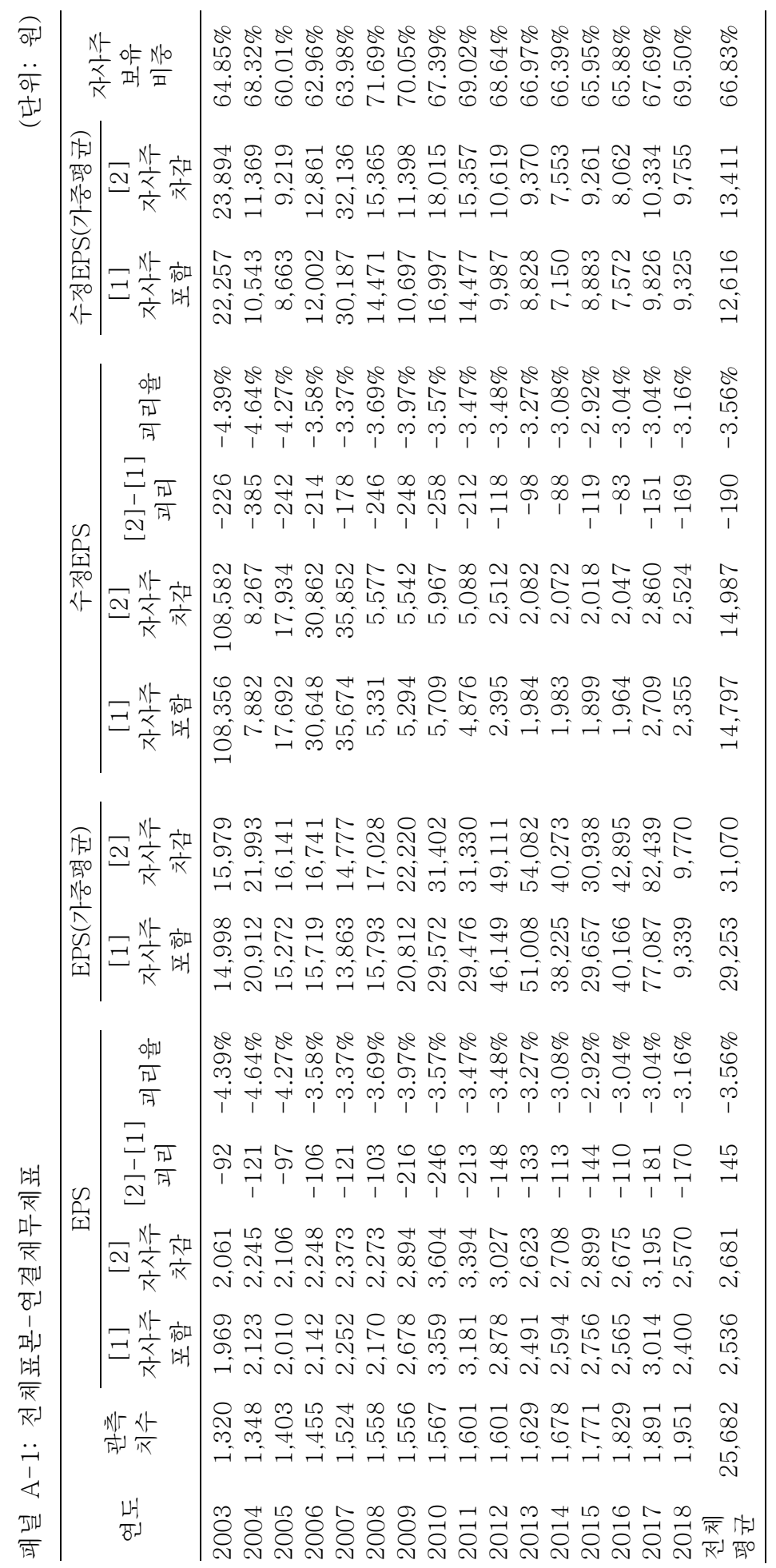




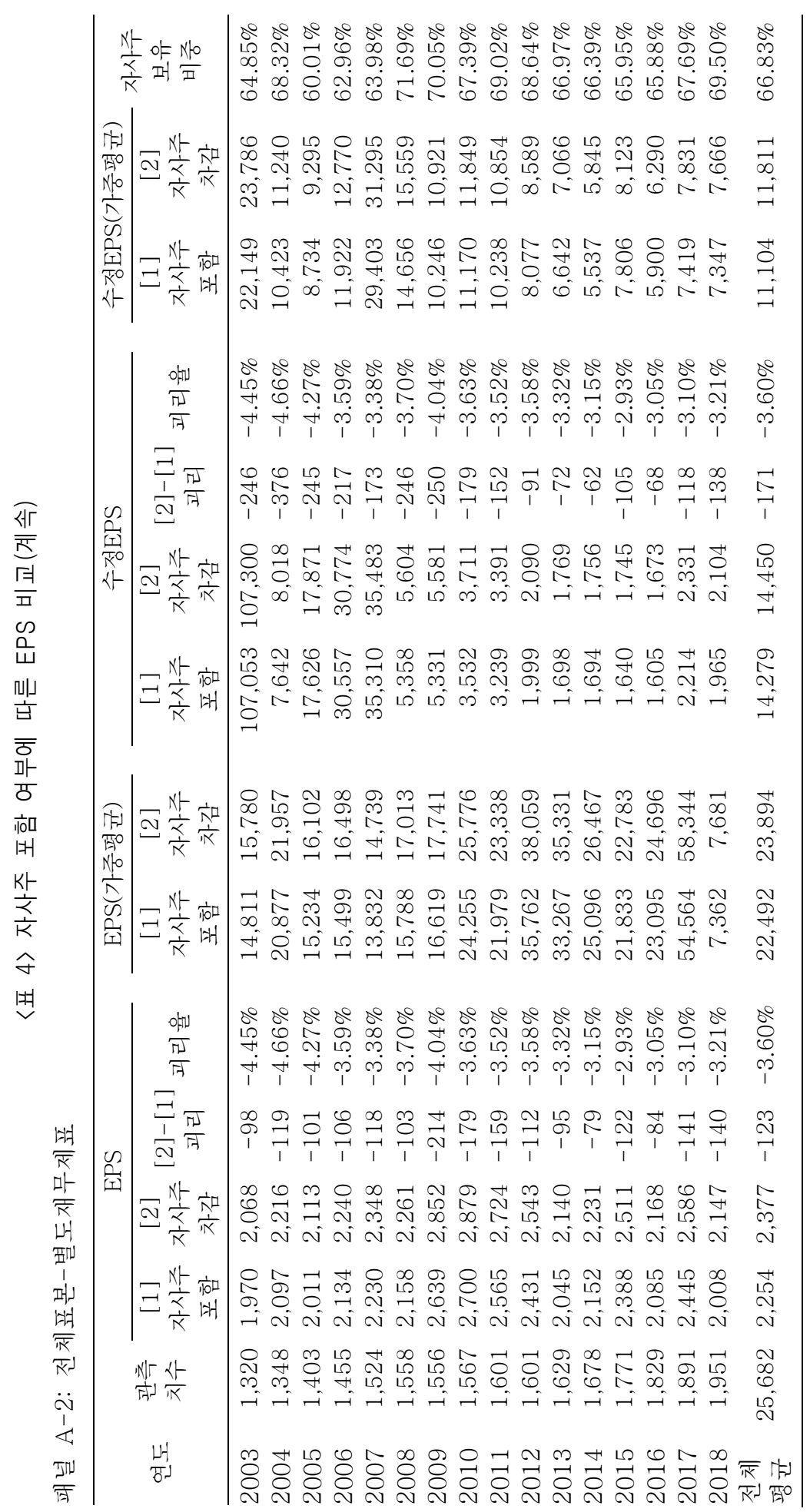




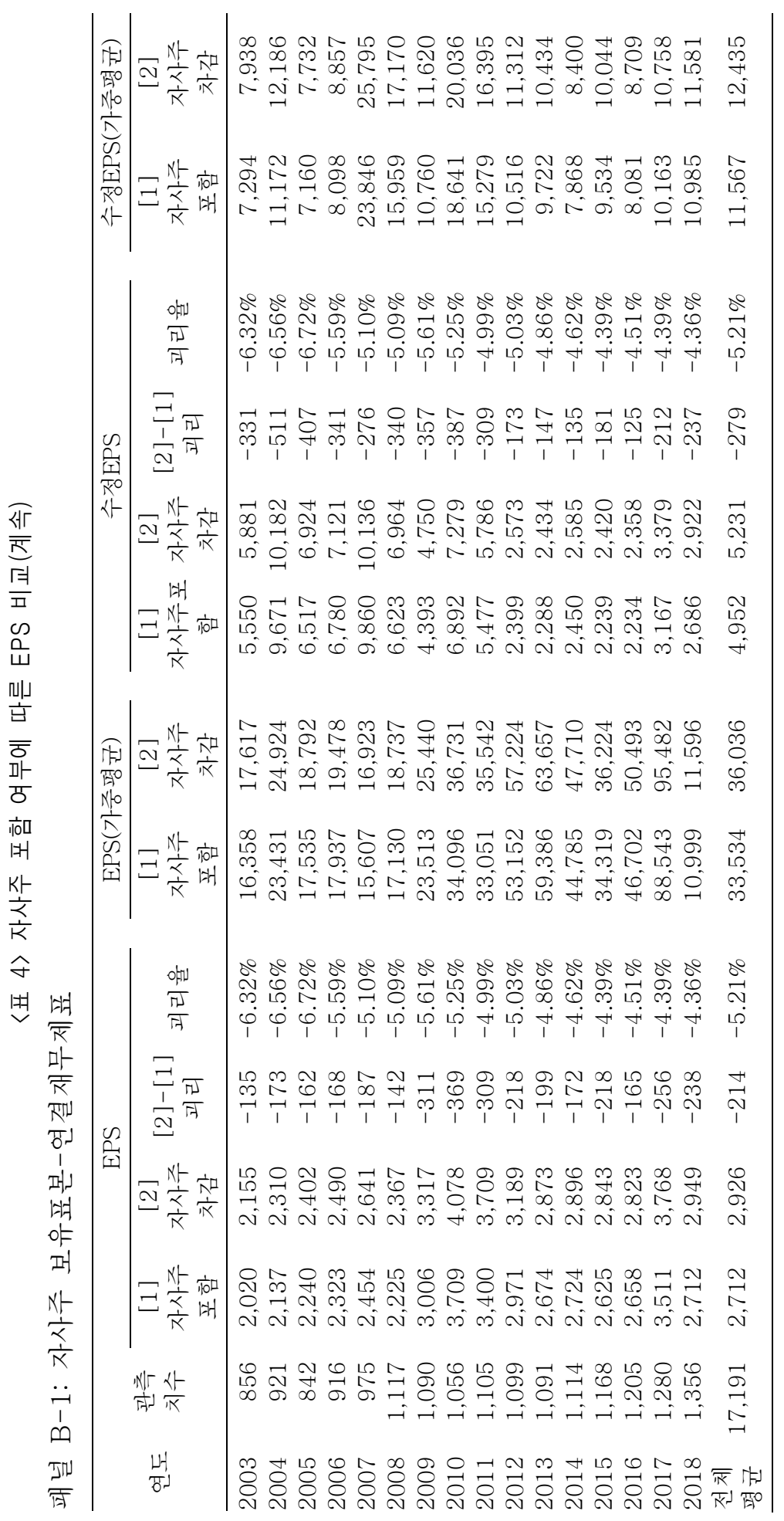




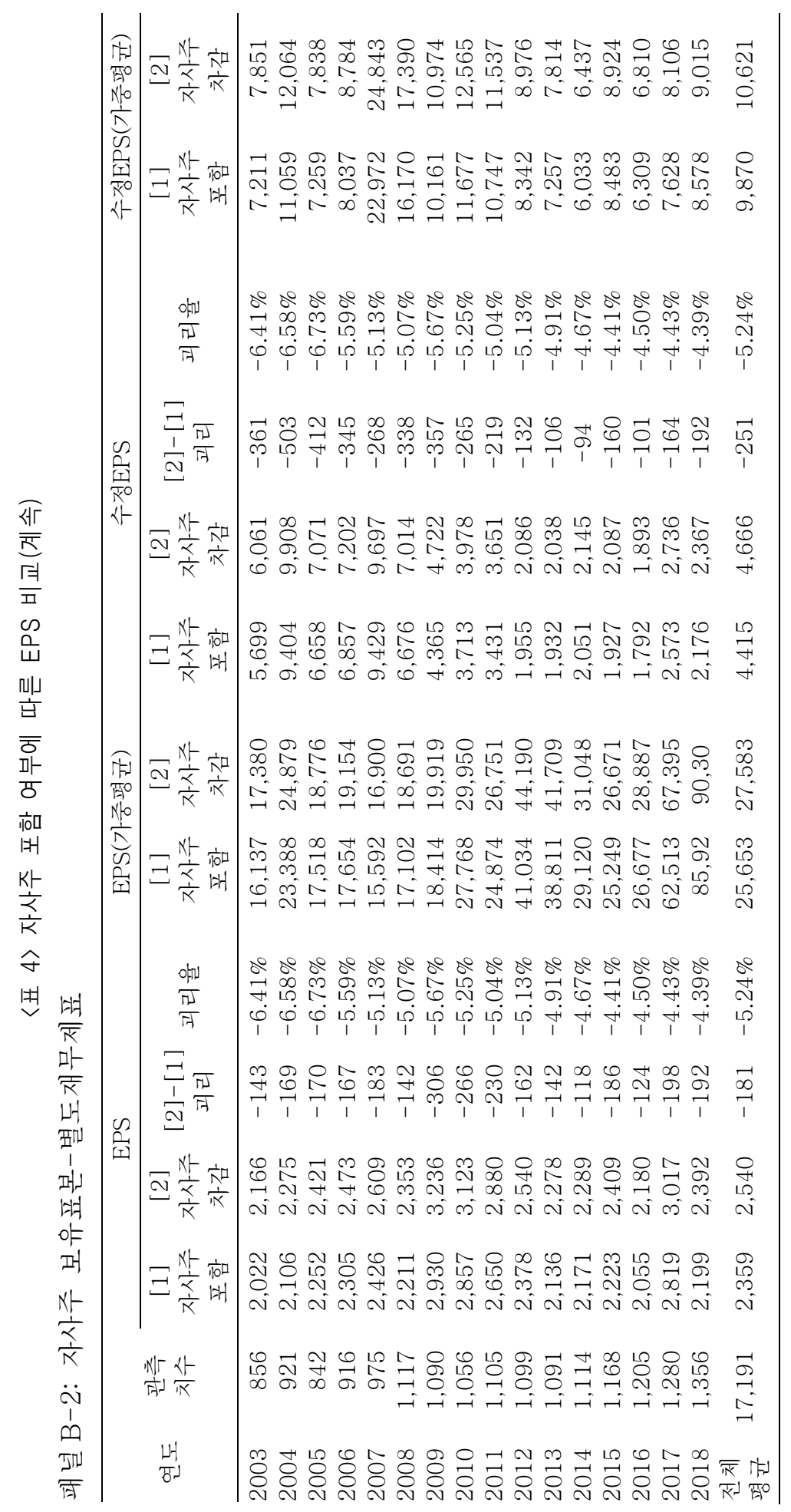


한국증권학회지 제49권 2호 (2020)

연도별 EPS는 주식시장의 상황에 따라서 변함을 알 수 있으나 괴리율은 <그림 1-1>에서 언급했듯이 전체 표본과 자사주 보유 표본에서 동시에 추세적으로 감소하고 있음을 알 수 있다. $\mathrm{EPS}$ 와 $\mathrm{EPS}$ (가중평균)는 많은 차이를 보이고 있으나 연도별 괴리율 변화 추이는 동일하여 표에는 보고하지 않았다. 아울러 동일 가중 $\mathrm{EPS}$ 는 연도별 변화가 상대적으로 안정적인 모습을 보이는 반면에 $\mathrm{EPS}$ (가중평균)는 상대적으로 높은 변동성을 보이고 있음을 알 수 있다.

EPS와 수정EPS의 단순 평균을 연도별로 비교해 보면 2003년부터 2007년까지 약 4배 정도 $\mathrm{EPS}$ 가 높으나 2008년 금융위기 이후부터는 차이가 약 0.85 수준으로 감소하는 추세를 보이고 있다. 반면에 시가총액으로 가중 평균한 $\mathrm{EPS}$ 와 수정EPS를 연도별로 비교해 보면 2007년에는 수정EPS가 EPS보다 약 1.5배 크나 점차 감소하여 2017년에는 약 0.12로 작아졌음을 알 수 있다. 이런 현상은 시가총액이 큰 주식의 EPS 혹은 수정EPS가 높기 때문에 나타난다. 따라서 자사주 포함 여부에 따른 차이 보다는 평균값을 구하는 방식 혹은 해당 연도에 따른 차이가 더 크게 변동함을 알 수 있다.

\section{3 주가 수익 비율(PER)}

<표 5>는 2003년부터 2019년까지 유가증권시장과 코스닥시장에 상장된 기업들의 자사주 포함 여부에 따른 연도별 평균 PER를 나타낸다. <표 4>의 $\mathrm{EPS}$ 와 수정EPS 결과에서 측정 규모의 차이는 존재하지만 괴리율은 동일한 값을 가지므로 본 소절에서는 평균주식수를 사용한 $\mathrm{PER}$ 에 대해서만 보고한다. 아울러 패널 $\mathrm{A}(\mathrm{A}-1 / \mathrm{A}-2), \mathrm{B}(\mathrm{B}-1 / \mathrm{B}-2)$ 구분은 $\mathrm{EPS}$ 분석과 같다.

PER 연도별 변화추이를 살펴보면 2008년 글로벌 금융위기로 2007년까지 증가하다가 2008년에 감소하지만 이후 지속적으로 증가하는 추세를 보이고 있다. 반면에 괴리율은 추세적으로는 감소하나 2008년 전후로 감소하다가 증가한 후 2015년까지 감소하다가 다시 소폭 증가하고 있다. 분석 기업을 유가증권시장과 코스닥시장 상장기업으로 확대해서 계산하면 코스닥시장의 PER 가중평균은 약 20 후반인 반면에 유가증권시장의 PER 가중 평균은 약 10 이다. 아울러 코스닥시장은 PER의 극단값이 많고 상장기업수가 많다는 사실을 고려하여 $\mathrm{PER}$ (중위값)도 같이 보고하고 있다. 특히 자사주 보유 표본을 대상으로 연결 재무제표를 사용한 분석 결과인 패널 B-1을 보면 PER(단순평균)과 $\mathrm{PER}$ (중위값)이 $6.12 \%$, $3.14 \%$ 로 매우 큰 차이가 있음을 볼 수 있다. 이런 결과는 다시 한번 PER를 이용한 IPO 공모가격 산정에 자사주 포함 여부가 중요함을 암시하고 있다.

\subsection{PER 과대평가와 IPO 공모가격}

$\mathrm{PER}$ 은 $\mathrm{IPO}$ 공모 가격 결정시 가장 널리 활용되는 상대가치 평가지표이다. 만약 비교의 대상이 되는 동종업종 유사기업의 PER가 자사주를 포함하는 관행에 따라 과대평가되어 있고, 과대평가된 유사기업의 PER가 공모 가격에 반영된다면, 추후 공모주에 투자한 일반 투자자의 수익률에 부정적인 영향을 미칠 가능성이 있다. 


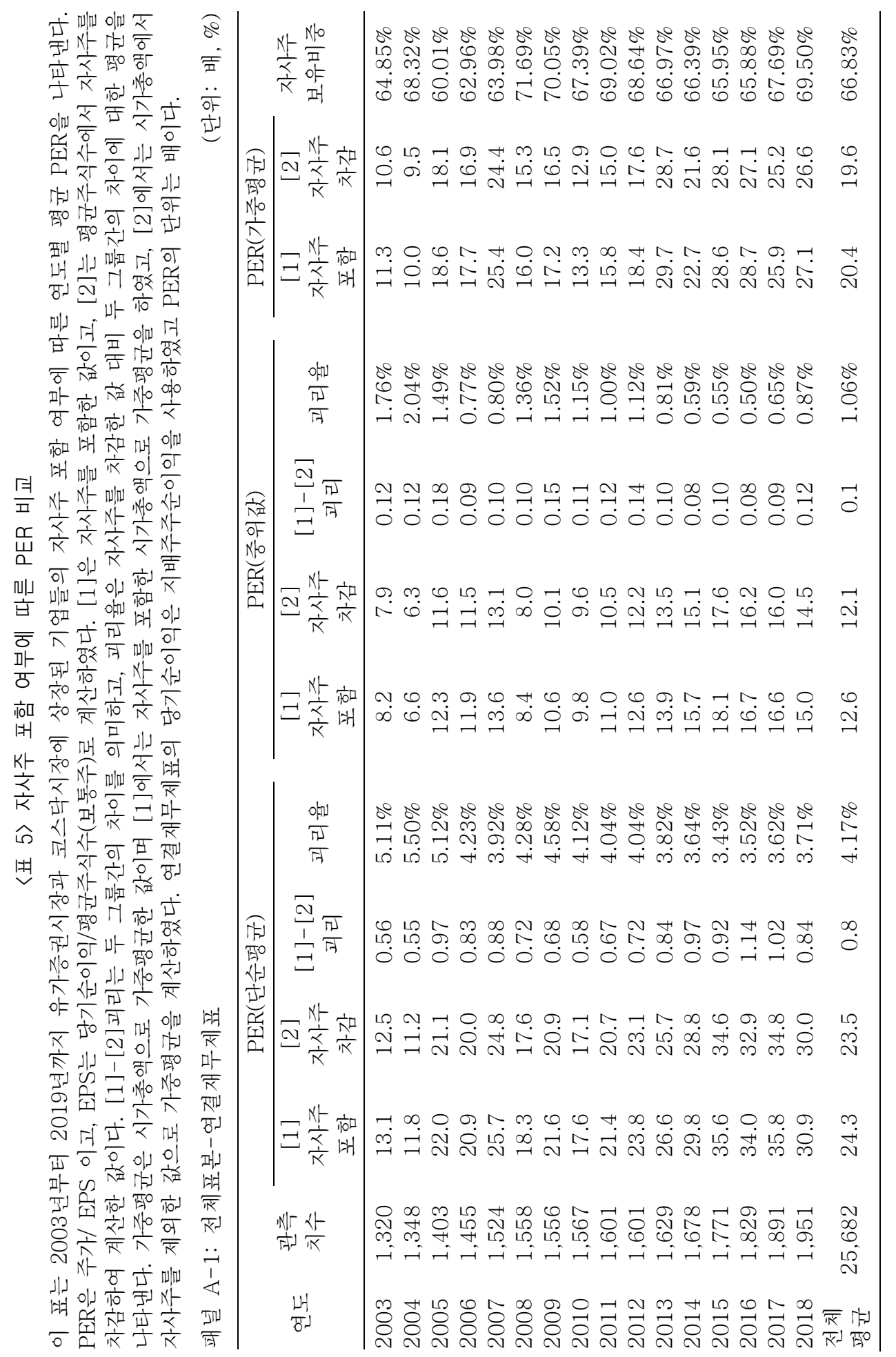




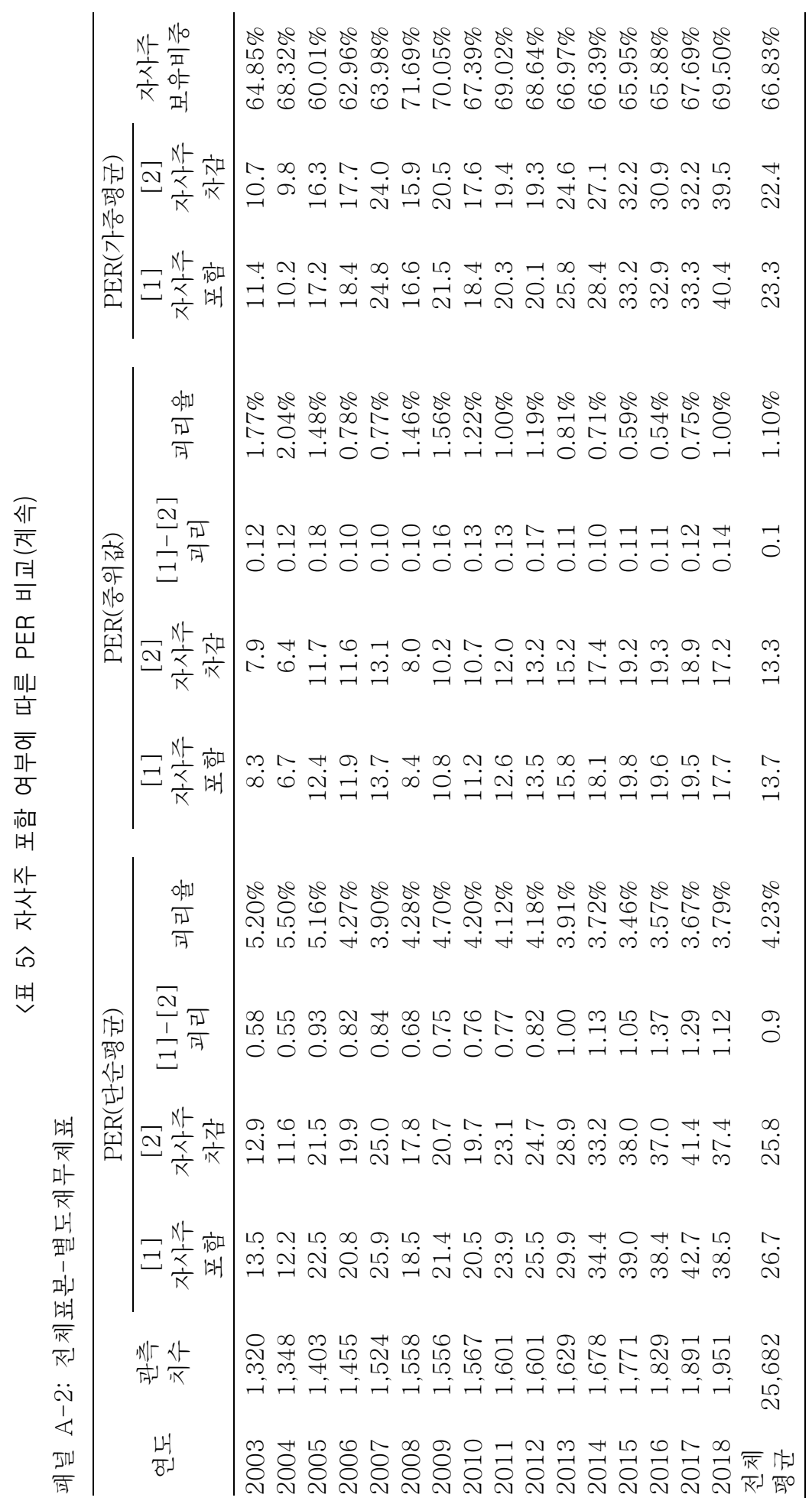




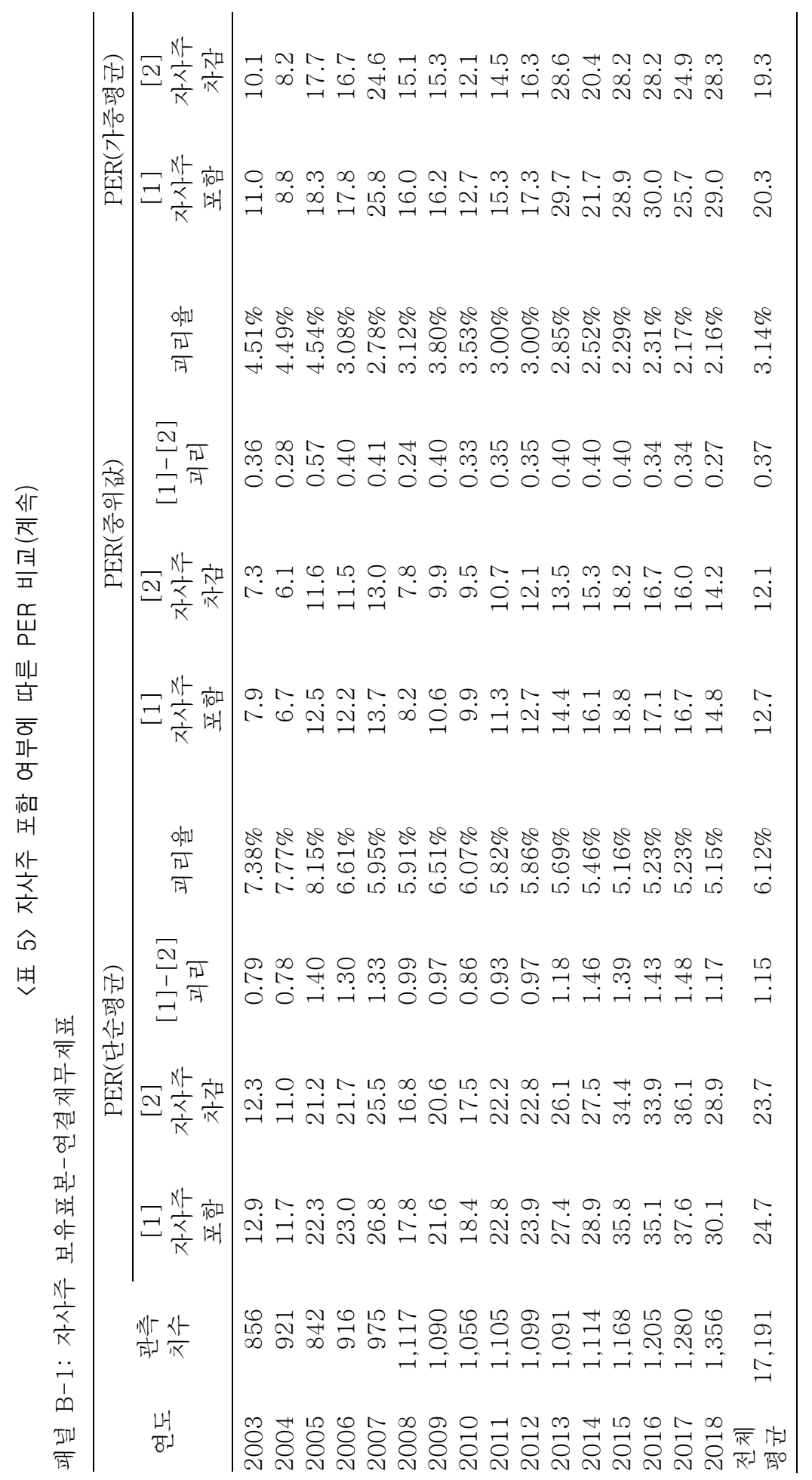




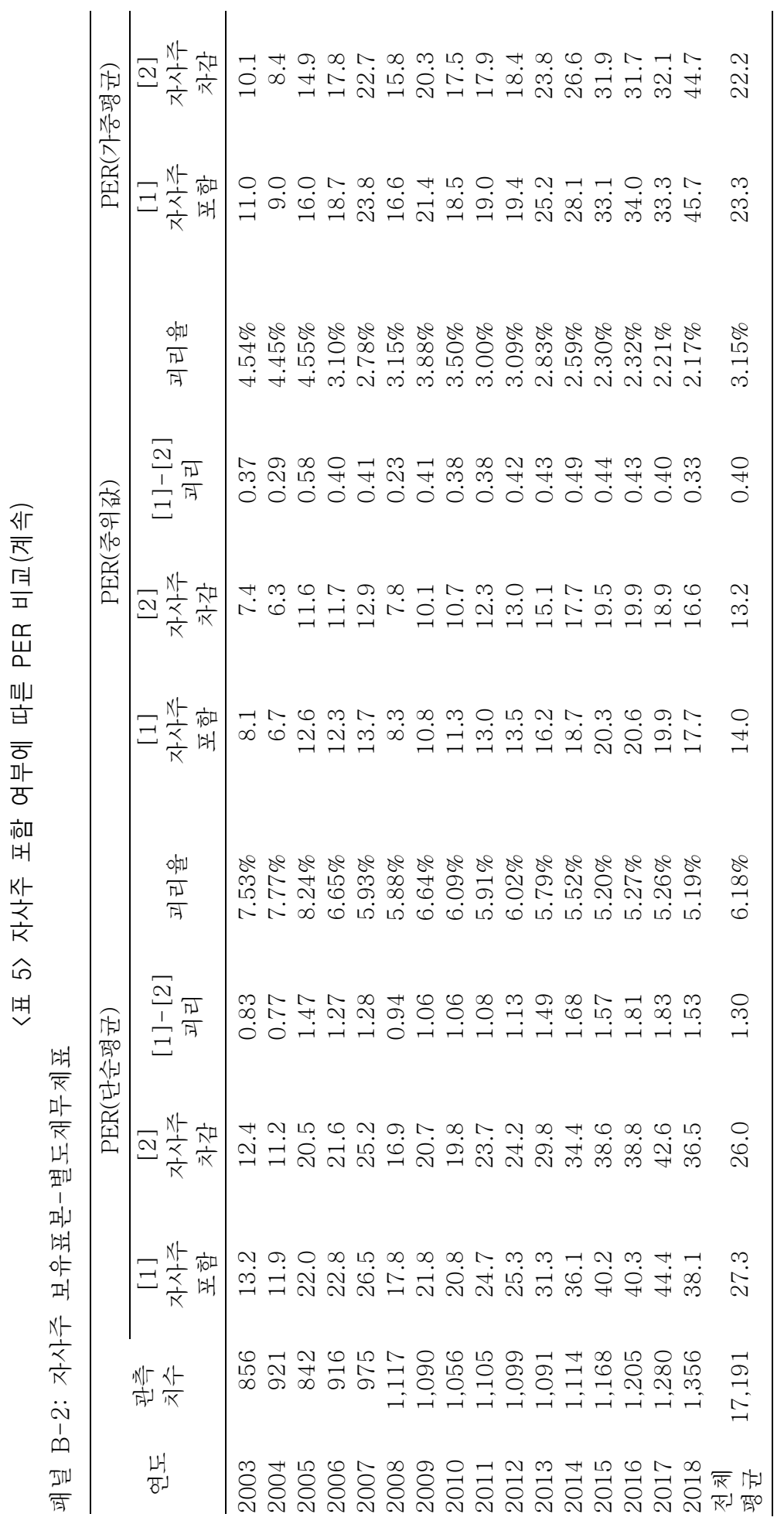


Effect of Including Treasury Shares in Market Capitalization, EPS, and PER

<표 6>에서는 자사주 포함 여부가 IPO 공모가격에 어느 정도의 영향을 미칠 수 있는지를 전체 자료를 대상으로 분석하기보다는 실제 사례를 통해 보여주고자 한다. 즉, 대규모 표본을 통한 통계 분석 대신 2018년 3월에 상장한 애경산업의 사례를 간략히 살펴본다. 애경산업은 생활용품 및 화장품의 제조 및 판매를 주요 업종으로 하는 애경그룹의 핵심 기업으로 1950년 대륭산업으로 창립되었다.

〈표 6〉PER 과대평가와 IPO 공모가액 사례(애경산업)

이 표는 2018년 3월에 상장한 애경산업의 동종업계 유사기업 평균PER배수를 자사주 포함 여부에 따라 그 차이를 비교한 것이다. 해당 자료는 전자공시시스템(DART)에서 2018년 2월 28일자 증권신고서 (지분증권)에 작성된 공시를 참고하였으며, 인수인의 의견(분석기관의 평가의견)에서 비교회사 $\mathrm{PER}$ 배수 산출 부분을 참고하여 작성하였다. 2017년 3분기 연환산 기준으로 동종업 계 유사기업의 $\mathrm{PER}$ 을 산정하였고, 연환산 순이익은 $(3$ 분기 누적순이익 $/ 3) \times 4$ 로 계산하였다. 발행주식총수는 분석 기준일 당시의 상장주식총수이고, 주당순이익은 연환산 분기순이익/발행주식총수로 계산하고, 기준주가는 $\operatorname{Min}$ (분석기준일로부터 1 개월간 종가 산술평균, 분석기준일 종가)로 산정하였다. 평균 PER은 비경상적 PER이라 판단되는 (주)잇츠한불을 제외한 PER의 산술평균이다.

\begin{tabular}{|c|c|c|c|c|c|c|}
\hline 구분 & $\begin{array}{l}\text { 에이블 } \\
\text { 씨엔씨 }\end{array}$ & $\begin{array}{l}\text { 아모레 } \\
\text { 퍼시픽 }\end{array}$ & $\begin{array}{c}\mathrm{LG} \\
\text { 생활건강 }\end{array}$ & $\begin{array}{l}\text { 제이준 } \\
\text { 코스메틱 }\end{array}$ & 잇츠한불 & 네오팜 \\
\hline \multicolumn{7}{|l|}{ 패널 A: 공시자료 } \\
\hline $\begin{array}{l}\text { 분기순이익(백만원) } \\
\text { 연환산순이익(백만원) } \\
\text { 발행주식총수(주) } \\
\text { 주당순이익(원) } \\
\text { 기준주가(원) } \\
\mathrm{PER(배)} \\
\text { 적용여부 } \\
\text { 평균 } \mathrm{PER(배)}\end{array}$ & $\begin{array}{r}6,556 \\
8,741 \\
16,890,782 \\
518 \\
18,098 \\
34.97 \\
0\end{array}$ & $\begin{array}{r}377,140 \\
502,853 \\
69,016,320 \\
7,286 \\
299,500 \\
41.11 \\
0\end{array}$ & $\begin{array}{r}526,065 \\
701,419 \\
15,618,197 \\
44,910 \\
1,177,000 \\
26.21 \\
0 \\
29.32 \\
\end{array}$ & $\begin{array}{r}25,231 \\
33,642 \\
26,481,470 \\
1,270 \\
16,134 \\
12.7 \\
0\end{array}$ & $\begin{array}{r}10,509 \\
14,012 \\
21,929,315 \\
639 \\
56,570 \\
88.54 \\
\mathrm{X}\end{array}$ & $\begin{array}{r}8,651 \\
11,535 \\
7,461,237 \\
1,546 \\
48,875 \\
31.61 \\
\bigcirc\end{array}$ \\
\hline \multicolumn{7}{|l|}{ 패널 $\mathrm{B}$ : 자사주차감 계산 } \\
\hline $\begin{array}{l}\text { 분기순이익(백만원) } \\
\text { 연환산순이익(백만원) } \\
\text { 발행주식총수(주) } \\
\text { 자기주식수(주) } \\
\text { 발행주식총수-자사주 } \\
\text { 주당순이익(원) } \\
\text { 기준주가(원) } \\
\text { PER(배) } \\
\text { 적용여부 } \\
\text { 평균 PER(배) }\end{array}$ & $\begin{array}{r}6,556 \\
8,741 \\
16,890,782 \\
262915 \\
16,627,867 \\
526 \\
18,098 \\
34.43 \\
\bigcirc\end{array}$ & $\begin{array}{r}377,140 \\
502,853 \\
69,016,320 \\
33041 \\
68,983,279 \\
7289 \\
299,500 \\
41.09 \\
0\end{array}$ & $\begin{array}{r}526,065 \\
701,419 \\
15,618,197 \\
958411 \\
14,659,786 \\
47846 \\
1,177,000 \\
24.60 \\
0 \\
28.53\end{array}$ & $\begin{array}{r}25,231 \\
33,642 \\
26,481,470 \\
304778 \\
26,176,692 \\
1285 \\
16,134 \\
12.55 \\
\bigcirc\end{array}$ & $\begin{array}{r}10,509 \\
14,012 \\
21,929,315 \\
4312720 \\
17,616,595 \\
795 \\
56,570 \\
71.12 \\
\mathrm{X}\end{array}$ & $\begin{array}{r}8,651 \\
11,535 \\
7,461,237 \\
386733 \\
7,074,504 \\
1631 \\
48,875 \\
29.98 \\
0\end{array}$ \\
\hline
\end{tabular}

애경산업의 공모가격을 결정할 당시 동종업계 유사기업은 에이블씨엔씨, 아모레퍼시픽, LG생활건강, 제이준코스메틱, 잇츠한불, 네오팜 등 총 6개 기업이었으며, 이 중 PER가 88배에 달했던 잇츠한불을 제외한 나머지 5개사의 PER 평균인 29.32가 적용되었다. 포함된 5개사 모두 자사주를 보유하고 있어서 PER가 과대평가되어 있었으며, 괴리율이 가장 높은 기업은 $\mathrm{LG}$ 생활건강으로 $6.5 \%$ 를 기록하였다. 
당초 공시자료에 보고된 5개사의 평균 $\mathrm{PER}$ 는 29.32이었으나, 자사주를 제외하고 평균 $\mathrm{PER}$ 을 재계산할 경우 28.53 로 $2.8 \%$ 감소하는 것으로 나타났다. 위 사례는 자사주 포함 여부가 상대가치평가를 통해 IPO 공모가격에도 영향을 미칠 수 있다는 사례를 보여준다.

\subsection{Fama-French 3요인 모형}

<표 7>에서는 Fama-French 3요인 모형과 동일한 방법으로 구성한 모방 포트폴리오인 $\mathrm{SMB}$ 와 $\mathrm{HML}$ 및 시장 포트폴리오 $\mathrm{RM}$ 의 기초 통계량을 보고한다. 자사주 포함 여부에 따른 평균, 표준편차, (피어슨) 상관계수에서의 큰 차이점은 없어 보인다. HML과의 상관관계에서 상관계수의 크기가 다소 큰 특징을 보이고 있다.

\section{〈표 7〉Fama-French 3요인 모형 기초통계량}

이 표는 시장포트폴리오와 2개의 모방포트폴리오들의 기초통계량을 나타낸다. SMB, HML은 Fama and French(1993)의 3요인 모형과 동일한 방법으로 구성하였다. 표본은 유가증권시장과 코스닥시장에 상장되어 있는 비금융업 회사들을 대상으로 하였고, 표본 기간은 자기주식 자료 확보가 가능한 2003년부터 2019년 7월까지의 주 별 자료를 사용하였다. [1]은 주식수에 자기주식을 포함하여 시가 총액을 계산한 뒤 모방포트폴리오를 구축하였고, [2]는 주식수에서 자기주식을 차감한 뒤 시가총액을 계산하여 모방포트폴리오를 구축하였다. 패널 $\mathrm{A}$ 는 각 요인들의 기초통계량을 보여주고, 패널 $\mathrm{B}$ 는 요인 간의 피어슨 상관계수를 보여주며 괄호 안에 $\mathrm{p}$-value값을 명시하였다.

패널 $\mathrm{A}$ : 기초통계

\begin{tabular}{|c|c|c|c|c|c|c|c|}
\hline \multirow[b]{2}{*}{ 변수 } & \multicolumn{3}{|c|}{ [1] 자사주 포함 } & \multicolumn{4}{|c|}{ [2] 자사주 차감 } \\
\hline & 평균 & 표준편차 & t-value & 평균 & 표준편차 & t-value & $\mathrm{N}$ \\
\hline $\mathrm{RM}$ & 0.19 & 2.67 & 2.02 & 0.19 & 2.67 & 2.00 & 787 \\
\hline $\mathrm{RM}-\mathrm{RF}$ & 0.13 & 2.67 & 1.41 & 0.13 & 2.67 & 1.39 & 787 \\
\hline SMB & 0.11 & 2.11 & 1.48 & 0.12 & 2.08 & 1.56 & 787 \\
\hline HML & 0.24 & 1.56 & 4.30 & 0.25 & 1.56 & 4.46 & 787 \\
\hline
\end{tabular}

패널 $\mathrm{B}$ : 피어슨 상관계수

\begin{tabular}{lcccccccc}
\hline & \multicolumn{3}{c}{$[1]$} & \multicolumn{2}{c}{ 자사주 포함 } & & \multicolumn{4}{c}{ [2] 자사주 차감 } \\
\cline { 2 - 4 } \cline { 6 - 9 } 변수 & $\mathrm{RM}-\mathrm{RF}$ & $\mathrm{SMB}$ & $\mathrm{HML}$ & & $\mathrm{RM}-\mathrm{RF}$ & $\mathrm{SMB}$ & $\mathrm{HML}$ & $\mathrm{N}$ \\
\hline $\mathrm{RM}-\mathrm{RF}$ & 1 & -0.20651 & -0.21803 & & 1 & -0.19766 & -0.23481 & 787 \\
& & $(<.0001)$ & $(<.0001)$ & & & $(<.0001)$ & $(<.0001)$ & \\
$\mathrm{SMB}$ & & 1 & -0.2765 & & 1 & -0.2877 & 787 \\
& & & $(<.0001)$ & & & $(<.0001)$ & \\
$\mathrm{HML}$ & & & 1 & & & & 1 & 787 \\
\hline
\end{tabular}

<표 8>에서는 기업 규모와 $\mathrm{BE} / \mathrm{ME}$ 를 각각 5 분위로 분류한 후, $25(=5 \times 5)$ 개로 구성된 포트폴리오 초과수익률에 대한 기초통계량을 제공한다. 규모가 작을수록, 그리고 장부-시장가 비율이 높을수록 초과수익률이 커지는 현상은 자사주 포함 여부에 관계없이 일관되게 나타나고 있다. 
Effect of Including Treasury Shares in Market Capitalization, EPS, and PER

〈표 8〉Fama-French 3요인 모형 포트폴리오 수익률 기초통계량

이 표는 Fama and French(1993)의 3요인 모형에서 사용되는 기업규모와 장부-시장가 비율로 기준으로 구성된 $\mathrm{Size}-\mathrm{BE} / \mathrm{ME} 5 \times 5$ 포트폴리오 초과 수익률의 기초통계량을 보여준다. 표본은 유가증권시장과 코스닥시장에 상장되어 있는 비금융업 회사들을 대상으로 하였고, 표본기간은 자기주식 자료 확보가 가능한 2003 년부터 2019년 7월까지의 주별 자료를 사용하였다. [1]은 주식수에 자기주식을 포함하여 시가총액을 계산한 뒤 모방포트폴리오를 구축하였고, [2]는 주식수에서 자기주식을 차감한 뒤 시가 총액을 계산하여 구축하였다.

\begin{tabular}{|c|c|c|c|c|c|c|c|c|c|c|}
\hline \multicolumn{4}{|c|}{ [1] 자사주 포함 } & \multicolumn{6}{|c|}{ Book-to-market equity (BE/ME) } & \multirow[b]{2}{*}{ High } \\
\hline \multirow[t]{2}{*}{ Size } & Low & 2 & 3 & 4 & High & Low & 2 & 3 & 4 & \\
\hline & \multicolumn{5}{|c|}{ 평균 } & \multicolumn{5}{|c|}{ 표준편차 } \\
\hline Small & 0.27 & 0.40 & 0.48 & 0.50 & 0.51 & 4.40 & 4.10 & 3.25 & 3.27 & 2.97 \\
\hline 2 & 0.12 & 0.22 & 0.29 & 0.35 & 0.39 & 4.14 & 3.58 & 3.29 & 3.16 & 2.92 \\
\hline 3 & 0.02 & 0.12 & 0.22 & 0.30 & 0.36 & 3.74 & 3.46 & 3.21 & 2.95 & 2.86 \\
\hline 4 & -0.01 & 0.10 & 0.18 & 0.28 & 0.33 & 3.67 & 3.27 & 2.97 & 2.84 & 2.89 \\
\hline Big & 0.01 & 0.16 & 0.15 & 0.30 & 0.24 & 3.12 & 2.90 & 3.17 & 3.14 & 3.43 \\
\hline \multicolumn{6}{|c|}{ t-value } & & & & & \\
\hline Small & 1.71 & 2.76 & 4.18 & 4.32 & 4.79 & & & & & \\
\hline 2 & 0.83 & 1.74 & 2.45 & 3.10 & 3.79 & & & & & \\
\hline 3 & 0.16 & 0.95 & 1.92 & 2.82 & 3.49 & & & & & \\
\hline 4 & -0.09 & 0.86 & 1.65 & 2.76 & 3.20 & & & & & \\
\hline Big & 0.13 & 1.58 & 1.37 & 2.70 & 1.99 & & & & & \\
\hline [2] 자스 & 차감 & \multicolumn{9}{|c|}{ Book-to-market equity (BE/ME) } \\
\hline \multirow[t]{2}{*}{ Size } & Low & 2 & 3 & 4 & High & Low & 2 & 3 & 4 & High \\
\hline & \multicolumn{5}{|c|}{ 평균 } & \multicolumn{5}{|c|}{ 표준편차 } \\
\hline Small & 0.29 & 0.32 & 0.53 & 0.52 & 0.48 & 4.57 & 3.77 & 3.44 & 3.24 & 2.98 \\
\hline 2 & 0.10 & 0.20 & 0.27 & 0.34 & 0.42 & 4.13 & 3.53 & 3.29 & 3.16 & 2.92 \\
\hline 3 & -0.01 & 0.12 & 0.24 & 0.24 & 0.36 & 3.74 & 3.42 & 3.26 & 2.95 & 2.82 \\
\hline 4 & -0.01 & 0.10 & 0.18 & 0.28 & 0.34 & 3.70 & 3.29 & 3.04 & 2.86 & 2.87 \\
\hline \multirow[t]{2}{*}{ big } & 0.01 & 0.16 & 0.17 & 0.28 & 0.20 & 3.05 & 2.95 & 3.04 & 3.08 & 3.48 \\
\hline & \multicolumn{5}{|c|}{ t-value } & & & & & \\
\hline Small & 1.78 & 2.41 & 4.33 & 4.52 & 4.52 & & & & & \\
\hline 2 & 0.69 & 1.56 & 2.34 & 3.04 & 4.05 & & & & & \\
\hline 3 & -0.06 & 0.97 & 2.03 & 2.31 & 3.54 & & & & & \\
\hline 4 & -0.06 & 0.90 & 1.69 & 2.77 & 3.34 & & & & & \\
\hline Big & 0.09 & 1.56 & 1.60 & 2.52 & 1.59 & & & & & \\
\hline
\end{tabular}

<표 9 >는 기업 규모와 $\mathrm{BE} / \mathrm{ME}$ 를 기준으로 $(2 \times 3)$ 와 $(5 \times 5)$ 포트폴리오를 구성하였을 경우, 자사주 포함여부에 따른 두 가지 경우에서의 구성 종목 중복률을 계산하였다. $2 \times 3$ 포트폴리오에서는 포트폴리오 구분의 폭이 커서 중복률이 $93 \%$ 이상이고 그 중에서 $\mathrm{BE} / \mathrm{ME}$ 가 Low인 포트폴리오 중복률이 $96 \%$ 로 높았다. 반면에 $5 \times 5$ 포트폴리오로 구분 폭을 축소한 결과 25개 포프폴리오의 중복률이 최소 $81 \%$ 로 감소하였다. 특히 기업 규모 2 3분위와 $\mathrm{BE} / \mathrm{ME} \mathrm{3} \mathrm{4분위에서} \mathrm{중복률이} \mathrm{감소하는} \mathrm{것을} \mathrm{알} \mathrm{수} \mathrm{있다.}$ 
〈표 9〉Size-BE/ME 포트폴리오의 구성 종목 중복률

이 표는 앞에서 구축한 [1]자사주 포함 자료와 [2]자사주 차감 자료의 Size-BE/ME 포트폴리오의 구성 종목이 얼마나 중복되는지 두 그룹간 중복률을 보여준다. 자사주 차감 자료를 기준으로 두 그룹간의 구성 종목 중복률을 계산했으며, 패널 $\mathrm{A}$ 는 $\mathrm{Size}-\mathrm{BE} / \mathrm{ME} 2 \times 3$ 포트폴리오이고, 패널 $\mathrm{B}$ 는 $\mathrm{Size}-\mathrm{BE} / \mathrm{ME}$ $5 \times 5$ 포트폴리오이다.

패널 $\mathrm{A}: \mathrm{Size}-\mathrm{BE} / \mathrm{ME} 2 \times 3$ 포트폴리오

\begin{tabular}{cccc}
\hline & \multicolumn{3}{c}{ Book-to-market equity(BE/ME) } \\
\cline { 2 - 4 } SIZE Small(50\%) & Low(30\%) & Medium(40\%) & High(30\%) \\
& 0.96 & 0.94 & 0.94 \\
\multirow{2}{*}{ Big(50\%) } & $(0.18)$ & $(0.24)$ & $(0.23)$ \\
& 0.96 & 0.93 & 0.93 \\
& $(0.19)$ & $(0.25)$ & $(0.25)$ \\
\hline
\end{tabular}

패널 $\mathrm{B}: \mathrm{Size}-\mathrm{BE} / \mathrm{ME} 5 \times 5$ 포트폴리오

\begin{tabular}{crrrrr}
\hline & \multicolumn{5}{c}{ Book-to-market equity(BE/ME) } \\
\cline { 2 - 6 } SIZE Small & \multicolumn{1}{c}{ Low } & \multicolumn{1}{c}{3} & \multicolumn{1}{c}{4} & High \\
& 0.96 & 0.91 & 0.87 & 0.84 & 0.89 \\
\multirow{2}{*}{2} & $(0.20)$ & $(0.28)$ & $(0.34)$ & $(0.37)$ & $(0.31)$ \\
& 0.90 & 0.85 & 0.81 & 0.81 & 0.82 \\
\multirow{2}{*}{3} & $(0.31)$ & $(0.36)$ & $(0.39)$ & $(0.39)$ & $(0.38)$ \\
& 0.88 & 0.85 & 0.83 & 0.80 & 0.85 \\
\multirow{2}{*}{4} & $(0.32)$ & $(0.36)$ & $(0.38)$ & $(0.40)$ & $(0.36)$ \\
& 0.92 & 0.86 & 0.82 & 0.83 & 0.87 \\
\multirow{2}{*}{ Big } & $(0.28)$ & $(0.35)$ & $(0.38)$ & $(0.38)$ & $(0.33)$ \\
& 0.95 & 0.91 & 0.85 & 0.84 & 0.92 \\
& $(0.22)$ & $(0.28)$ & $(0.36)$ & $(0.36)$ & $(0.28)$ \\
\hline
\end{tabular}

향후 연구에서는 자사주 포함 여부에 따라 SMB와 HML 모방 포트폴리오 구성에 차이가 발생하는지에 대한 통계적인 유의성 검증과 주식 수익률 횡단면에 미치는 다각적인 연구가 필요하다고 판단된다.

\section{4. 결론}

자기주식 또는 기매입된 자사주는 회계적으로 자본 차감 계정이고, 배당권과 의결권도 인정되지 않는다. 이에 따라 재무이론에서 자사주 취득은 취득 시점에서 주주환원정책의 일환으로 이해하는 것이 일반적이다. 그럼에도 불구하고, 국내에서는 시가총액 계산시 자사주를 포함한 발행주식 총수를 기준으로 함으로써 시가총액 및 $\mathrm{PER}$ 의 과대평가와, $\mathrm{EPS}$ 의 과소 평가를 야기하고 있다. 
Effect of Including Treasury Shares in Market Capitalization, EPS, and PER

본 연구에서는 시가총액 및 주당지표 산출시 자사주를 포함하는 관행이 이들 지표에 미치는 왜곡의 정도를 국내 최초로 계량적으로 분석하였다. ${ }^{7)}$ 전체(자사주 보유)표본을 이용한 실증 분석 결과, 시가총액은 평균 약 $6 \%(8 \%)$ 정도, $\mathrm{PER}$ 은 약 $4.2 \%(6.1 \%)$ 정도 과대평가되고 있으며, EPS는 약 3.6\%(5.2\%) 정도 과소평가 되고 있음을 발견하였다. Fama-French 3 요인 모형의 $5 \times 5$ 검증 포트폴리오 역시 최대 $20 \%$ 까지 구성 종목이 상이함을 알 수 있었다.

위와 같은 연구 결과는 시가총액 및 주당지표 산출시 자사주를 기계적으로 포함하는 국내의 관행에 변화가 필요함을 시사한다. 즉, 국내에서도 미국과 같이 매입 시점에서 자사주를 시가 총액에서 제외하도록 함으로써 시가 총액의 과대평가 및 주가 지수의 왜곡을 방지하고, 자사주 매입의 주주환원 정책(payout policy)으로서의 성격을 명확히 할 필요가 있다.

물론 상장기업의 자사주 매입은 장내에서 실시간으로 이루어지며, 이에 따라 이를 적시에 정확하게 반영하는 것은 실무상으로 추가적인 자원 투하가 요구되는 문제일 수 있다. 그러나 국제기준과의 일관성, 비교 가능성 및 논리적 정합성 ${ }^{8)}$ 을 위해서는 지표의 목적에 맞게 자사주의 포함 여부를 결정하는 방식이 더 타당하다고 생각된다. 즉, 단순한 주식시장 규모를 나타내는 지표에서는 자사주 포함 여부가 투자에 미치는 영향은 크지 않지만, 투자 판단의 기준으로 사용되는 지표에서는 자사주를 포함하지 않은 것이 국제적인 정합성 및 투자지표로 유용하다고 판단된다.

현실적으로는 시가총액 및 주당지표에서 자사주를 일시에 제외하는 추진 방식은 매우 어려울 것으로 사료된다. 현재 국내 애널리스트들이 사용하는 대표적인 목표주가 산정 방식은 “목표 PER×추정 EPS”으로서 위 식에 포함되는 핵심 구성요소인 PER과 EPS에 자사주가 모두 반영되어 있으므로 이를 일시에 변경하는 것은 실무적으로 큰 혼란이 있을 수 있기 때문이다.

따라서 자료 제공 업체에서는 자사주를 제외한 시가총액 및 주당지표를 일단 보조지표로 제공하면서 실무에서 이를 활용할 수 있도록 지원하고, 학계에서부터 자사주 제외 지표를

7) 자사주 포함 관행이 시장가 대 장부가 비율(market to book ratio) 및 토빈의 Q(Tobin's Q)에도 영향을 미칠 수 있다. 이런 주제는 자사주 보유, 처분 매각이 기업가치에 미치는 영향이라는 향후 연구에서 심층적으로 분석할 예정이다.

8) 예를 들어, e-나라지표 사이트(http://www.index.go.kr/potal/main/EachDtlPageDetail.do?idx_cd=1079) 에서 제공하는 금융위원회-상장회사수, 시가총액 지표에서는 자사주 포함 시가총액을 제공한다. 이는 WFE(World Federation Exchanges)의 통계 정의[Market capitalization is the total number of issued shares of Domestic Companies, including their several classes, multiplied by their respective prices at a given time]와 일치한다. 하지만 WFE의 PER 통계 정의[The PER is calculated by dividing the market capitalization by the total market earnings]는 일반기업회 계기준과 같이 자사주를 포함하지 않은 유통주식수를 사용하여 시가총액을 계산한다. 
보다 적극적으로 활용하여 점진적으로 자사주 제외 지표가 업계에서 사용될 수 있도록 유도하는 것이 보다 현실적인 접근 방법으로 사료된다. ${ }^{9)}$

본 연구의 한계 및 이와 관련된 추가 학술 연구 주제는 다음과 같다. 본 연구에서는 자사주를 제외한 요인 모형의 포트폴리오별 수익률은 구하였으나, 자사주 포함 여부가 실제로 자산 가격결정모형의 추정 결과에 어떠한 영향을 미치는가에 대해서는 분석하지 못하였다. 자사주 포함 여부가 각 자산가격결정모형의 주식 수익률 횡단면에 대한 설명력에 미치는 영향을 분석하는 것은 매우 중요한 향후 연구 과제로 사료된다. 한편, 자사주 제외에 따른 시가총액의 변화는 시가총액을 가중치로 하는 주가지수에도 영향을 미치게 되는데, 본 연구에서는 이를 본격적으로 다루지 못했다. 주가지수의 변화는 모든 자산가격결정모형의 주요 독립변수인 시장수익률의 변화를 의미하므로, 시장수익률 변화에 따른 자산가격결정모형에의 영향도 분석할 필요가 있다.

아울러 PER의 과대평가와 IPO 공모가격과의 관계 역시 대규모 표본을 통한 통계 분석은 실시하지 못하고 단일 사례 분석을 시행하였다. 향후 대규모 표본 구성을 통해 $\mathrm{PER}$ 과대 평가와 IPO 공모가격 간의 관계를 분석하고, 중장기 공모주 투자 수익률에 어떤 영향을 미치는지 분석하는 것도 흥미로운 연구 과제로 사료된다.

9) $\mathrm{CBOE}$ 에서 1993년 도입한 변동성지수인 VIX사례가 많은 시사점을 준다. 도입시점에서 BlackScholes 모형하에서 산출한 등가격옵션 내재변동성(implied volatility)을 이용하여 산출하였으나 10년 후인 2003년에 Goldman Sachs와 CBOE가 모형에 대한 가정없이 이론적으로 도출한 산식을 이용하여 새로운 변동성지수를 개발하여 공표하였다. 기존 지수는 $\mathrm{VXO}$ 로 새롭게 개발된 지수는 VIX로 둘 다 공표하고 있다. 
Effect of Including Treasury Shares in Market Capitalization, EPS, and PER

\section{References}

Brealey, R. A., S. C. Myers, and F. Allen, Principles of Corporate Finance, McGraw-Hill Irwin, 2009.

CBOE, The CBOE Volatility Index - VIX, Chicago Board Options Exchange, Inc., 2009.

Fama, E. F., and K. R. French, 1995, Size and Book-to-Market Factors in Earnings and Returns, Journal of Finance, Vol. 50, pp. 131-155.

Fama, E. F., and K. R. French, 1996, Multifactor Explanations of Asset Pricing Anomalies, Journal of Finance, Vol. 51, pp. 55-84.

Fama, E. F., and K. R. French, 1993, Common Risk Factors in the Returns on Stocks and Bonds, Journal of Financial Economics, Vol. 33, pp. 3-56.

Kim, W., and J. Lim, 2017, An Empirical Study on Resale and Retirement of Treasury Shares: Evidence from Korea, Korean Journal of Financial Studies, Vol. 46 (1), pp. 35-60.

Korea Accounting Institute, Accounting Standards for Non-Public Entities, Chapter 26, Earnings per Share, Korea Accounting Standards Board, 2010.

Korea Exchange, KOSPI 200 Index Methodology Guide, Online report, 2017.

Korea Exchange, KRX Index Methodology Guide (KOSPI, Sector index), Online report, 2016.

WFE, WFE Statistics Definitions Manual (Revised July 2019), World Federation of Exchanges, 2019. 